\title{
HUBERT PŁOWIK
}

\section{Przywilej dla Błonia (1380 r.) na tle lokacji miast za panowania Janusza I Starszego*}

Niniejsza praca zawiera analizę przywileju, który wystawił książę Janusz I Starszy dla swojego miasta Błonia w 1380 r. W nim to nadał mieszczanom prawo stosowania prawa chełmińskiego, zwolnił ich z powinności prawa książęcego oraz opłat celnych na terenie całego kraju. Badanie porównawcze wykazuje, że takie same postanowienia zawierały przywileje nadawane później innym wspólnotom miejskim we wschodniej dzielnicy mazowieckiej. Aby przedstawić kontekst wystawienia przywileju, w pracy przedstawiony jest również zarys sytuacji politycznej i gospodarczej na Mazowszu w drugiej połowie XIV w., początki i przebieg lokacji na prawie niemieckim mazowieckich miast oraz dzieje Błonia przed 1380 r. Celem tej pracy była odpowiedź na pytanie o datę lokacji Błonia, mając na względzie istnienie co najmniej dwóch typów przywilejów, odgrywających w procesie lokacyjnym ważną rolę. Przywilej dla Błonia okazał się zamykającym ten proces, co pozwala przesunąć datę początków miasta wstecz.

Słowa kluczowe: Błonie, lokacje miejskie, prawo chełmińskie, Janusz I Starszy

* Niniejszy artykuł opiera się na pracy dyplomowej, obronionej na Wydziale Historii Uniwersytetu Warszawskiego. Za merytoryczne wsparcie pragnę podziękować mojemu promotorowi dr. hab. Grzegorzowi Myśliwskiemu. 
Błonie $\mathrm{w}$ powiecie warszawskim zachodnim województwa mazowieckiego zostało lokowane na prawie chełmińskim - zgodnie z dotychczasową literaturą - przez księcia Janusza I Starszego w 1380 r. Najstarszą pracą historyczną, w której stwierdzono ten fakt, jest pierwsze wydanie Starożytnej Polski... Michała Balińskiego i Tymoteusza Lipińskiego z $1843 \mathrm{r}^{1}{ }^{1}$ Za nimi pogląd ten przejmowali późniejsi badacze: Wincenty Hipolit Gawarecki, Julian Błeszczyński, Filip Sulimierski, Stanisław Pazyra i inni ${ }^{2}$. Natomiast lokalni autorzy pierwszej monografii miasta, lekarz Grzegorz Witold Nowakowski oraz geograf Jan Kamosiński, uznali ten przywilej za drugi w kolejności ${ }^{3}$. Wcześniejszy miał być wydany w Kodeksie dyplomatycznym Polski przywilej, w którym Władysław, książę krakowski, łęczycki i dobrzyński, nadaje wsi Błoniu prawo niemieckie w 1338 r. $^{4}$ Wiele lat później słusznie podważył go następny lokalny badacz Marcin Wojciech Solarz, niemniej kwestii tej całkowicie nie rozwiązał ${ }^{5}$. Sprawa jednak wydaje się prosta - ten przywilej dotyczył Błonia pod Łęczycą, za czym przemawia częściowo błędnie tytułowany wystawca - Władysław Garbaty oraz łęczyccy urzędnicy jako świadkowie ${ }^{6}$.

Przywilej dla Błonia z 1380 r. był natomiast drugim wydanym przez mazowieckiego księcia Janusza I, dotyczącym kwestii miejskiej. Pierwszy z 1378 r. został wystawiony dla książęcego miasta Różana. Analiza dwóch przywilejów różańskich autorstwa Janusza Grabowskiego ${ }^{7}$, a także sformułowana przez Stanisława Russockiego teza o powstawaniu mazowieckich miast w kilku etapach ${ }^{8}$, nasuwają pytania: czy przywilej ten możemy uznać za akt lokacyjny i kiedy rzeczywiście zostało lokowane miasto Błonie? Do odpowiedzi na te pytania niezbędne jest dokładne zbadanie postanowień błońskiego przywileju i zestawienie go z innymi przywilejami Janusza I dotyczącymi miast, skupiając się przede wszystkim na okresie do końca XIV w.

$1 \quad$ M. Baliński, T. Lipiński, Starożytna Polska pod względem historycznym, jeograficznym i statystycznym opisana, t. 1, Warszawa 1843, s. 473.

2 W.H. Gawarecki, Wiadomość historyczna o kościele parafialnym w mieście Błoniu, „Pamiętnik religijno-moralny"1848, t. 14, z. 5, s. 458; J. Błeszczyński, Błonie, [w:] S. Orgelbrand (red.), Encyklopedyja powszechna, t. 3, Warszawa 1860, s. 804; F. Sulimierski, Błonie, [w:] F. Sulimierski, B. Chlebowski, W. Walewski (red.), Słownik geograficzny Królestwa Polskiego i innych krajów słowiańskich, t. 1, Warszawa 1880, s. 249-250; S. Pazyra, Studia z dziejów miast na Mazowszu od XIII do poczqtków XX wieku, Lwów 1939, s. 60; tenże, Geneza i rozwój miast mazowieckich, Warszawa 1959, s. 114; M. Siuchniński (red.), Miasta polskie w tysiqcleciu, t. 2, Wrocław 1967, s. 457.

3 G.W. Nowakowski, J. Kamosiński, Przyczynek do dziejów m. Błonia województwa warszawskiego, Błonie 1930, s. 9.

4 L. Rzyszczewski, A. Muczkowski (wyd.), Kodex dyplomatyczny Polski, t. 2, cz. 2, Warszawa 1852, nr 491.

5 M.W. Solarz, Błonie. Ksiq̨żęce miasto na Mazowszu, Kwidzyn 2010, s. 21.

6 Por. J. Bieniak, A. Szymczakowa (oprac.), A. Gąsiorowski (red.), Urzędnicy łęczyccy, sieradzcy i wieluńscy XIII-XV wieku. Spisy, Wrocław 1985.

7 J. Grabowski, Przywileje lokacyjne księcia mazowieckiego Janusza I dla Różana, „Rocznik Mazowiecki” 2009, t. 21 s. 7-21.

8 S. Russocki, Etapy lokacji miejskich na Mazowszu w XIV-XV wieku, „Przegląd Historyczny” 1964, t. 55 , z. 2, s. 189-196. 
W niniejszej pracy za podstawę źródłową posłużył mi ujednolicony tekst przywileju, wydany drukiem w Nowym Kodeksie Dyplomatycznym Mazowsza ${ }^{9}$. Mimo to konieczna była konfrontacja edycji z rękopisami i korekta literówek, które potrafiły wręcz zmienić sens zdania. Poprawioną wersję przedstawiam w Aneksie 2.

Zanim jednak przejdę do analizy źródłowej, kolejno zarysuję sytuację polityczną i gospodarczą na Mazowszu w drugiej połowie XIV w., kwestie dotyczące prawa lokacyjnego (chełmińskiego) i powstawania miast na Mazowszu, a także dzieje Błonia przed $1380 \mathrm{r}$.

Głównym czynnikiem wpływającym na politykę i gospodarkę Mazowsza w połowie XIV w. było jego położenie geograficzne. Peryferyjny, ubogi, nieodgrywający ważnej roli na arenie międzynarodowej kraj graniczył wówczas z trzema potężnymi sąsiadami: Królestwem Polski, państwem zakonu krzyżackiego i Wielkim Księstwem Litewskim. Z Polską związany był językowo, kulturowo i historycznie, wszak w obu państwach rządzili monarchowie z rodu Piastów. Zakon krzyżacki sprawował kontrolę nad dolnym biegiem Wisły, głównej mazowieckiej arterii, co przekładało się na silne powiązania gospodarcze między oboma krajami. Litwini, pomimo prób poprawy stosunków na początku XIV w., wciąż pustoszyli Mazowsze łupieżczymi najazdami ${ }^{10}$.

Po śmierci księcia warszawskiego Kazimierza w 1355 r. na Mazowszu zostało dwóch piastowskich władców: król polski Kazimierz Wielki oraz książę mazowiecki Siemowit III Trojdenowic. Wówczas książę złożył królowi hołd, a ten nadał mu jego własną oraz warszawską dzielnicę $\mathrm{w}$ lenno, zachowując dla siebie ziemię płocką. Układ ten zawarto na dogodnych dla Siemowita warunkach, które m.in. gwarantowały uzyskanie przez Mazowsze niezależności oraz powrót Płocka do księstwa, gdyby Kazimierz Wielki nie pozostawił po sobie męskich potomków ${ }^{11}$.

Warunek ten ziścił się w 1370 r., więc zgodnie z umową wygasała zależność lenna Mazowsza i ziemie dotąd królewskie przechodziły pod panowanie Siemowita. Odzyskawszy pełną suwerenność, książę starał się utrzymywać dobre stosunki ze wszystkimi sąsiadami. W walce o sukcesję krakowskiego tronu nie opowiedział się po stronie żadnego z kandydatów. I choć nie zjawił się na koronacji Ludwika Węgierskiego, to później pozostawał z nim w poprawnych relacjach. Jednocześnie doprowadził do polepszenia stosunków z Litwą przez małżeństwo swojego najstarszego syna Janusza z Danutą Anną Kiejstutówną. Tak samo dobre relacje z zakonem krzyżackim przełożyły się na nasilenie kontaktów handlowych z Prusami i w konsekwencji przyspieszenie rozwoju gospodarczego księstwa ${ }^{12}$.

Polityka wewnętrzna Siemowita III opierała się na kontynuacji działań Kazimierza Wielkiego, zapoczątkowanych w ziemi płockiej, oraz na wdrażaniu rozwiązań znanych ze Śląska i Korony. Za sprawą księcia na całym Mazowszu

NKDM 3, nr 245.

10 H. Samsonowicz, A. Supruniuk, Dzieje polityczne (połowa XIV - poczqtek XVI w.), [w:] H. Samsonowicz (red.), Dzieje Mazowsza, t. 1, Pułtusk 2006, s. 258.

11 Tamże, s. 260-264.

12 Tamże, s. 266-269. 
ustanowiony został urząd starosty generalnego i starostów ziemskich, wykrystalizował się także podział terytorialny na ziemie oraz powiaty. W wyniku reform w dziedzinie sądownictwa powołano do życia regularne sądy i kancelarie ziemskie, skodyfikowano prawo, a w 1377 r. książę wydał pierwszy statut mazowiecki, wzorowany na statutach wiślicko-piotrkowskich Kazimierza Wielkiego. Siemowit rozpoczął również budowę zamków w Gostyninie i Wyszogrodzie ${ }^{13}$.

Na możliwość przeprowadzenia reform duży wpływ miał rozwój gospodarczy Mazowsza, które wychodziło z zapaści po łupieżczych najazdach Litwinów w poprzednich dziesięcioleciach. Dogodne położenie Mazowsza w dorzeczu środkowej Wisły, Narwi i Bugu, którędy przechodził szlak handlowy z Rusi do Prus, przełożyło się na późniejszą koniunkturę gospodarczą. I choć jeszcze do połowy XIV w. najważniejszą rolę na Mazowszu odgrywał tranzyt, to w drugiej połowie stulecia, a szczególnie od lat siedemdziesiątych, przeważał eksport mazowieckich towarów do głównego partnera handlowego - miast pruskich. Wówczas państwo zakonne przeżywało okres swojej świetności i wraz z Hanzą pośredniczyło w handlu surowcami (potrzebnymi np. w szkutnictwie i sukiennictwie) ze wschodu na zachód. Miasta mazowieckie stały się miejscami skupu oraz eksportu przede wszystkim produktów leśnych: drewna, smoły, wosku, popiołu, futerek, a także żywności. W zamian otrzymywano sukno lub gotówkę. Państwo zakonne było dla Mazowsza szczególnie istotne gospodarczo, gdyż wymiana z Prusami stanowiła ponad połowę jego obrotów zagranicznych, przy czym dla zakonu południowo-wschodni sąsiad odgrywał niewielką rolę ${ }^{14}$. W tym okresie nastąpiło również ożywienie na drodze wiodącej z Litwy w kierunku centralnej Polski i Śląska przez mazowieckie miasta, w tym Warszawę, które oferowały np. usługi rzemieślnicze dla karawan oraz swoje towary ${ }^{15}$.

Nasilenie kontaktów z zakonnymi Prusami przyczyniło się do wzmożonej obecności obcych kupców w księstwie Siemowita III, który starał się ułatwiać im działalność przez politykę „otwartych drzwi”, gwarancje bezpieczeństwa na drogach i umiarkowanych stawek w komorach celnych ${ }^{16}$. Ruch ludności między oboma krajami spowodował również wymianę nowych idei, np. upowszechnianie się gospodarki towarowo-pieniężnej, czynszów i prawa chełmińskiego na Mazowszu. Szacuje się, że w latach 1356-1381 Siemowit lokował na tymże prawie minimum dziewięć miast i wiele wsi, a także nadawał immunitety oraz ziemię na prawie chełmińskim, m.in. w ramach akcji kolonizacyjnej na zniszczonych,

13 Tamże, s. 273-275; J. Senkowski, Skarbowość Mazowsza od końca XIV wieku do 1526 roku, Warszawa 1965, s. 33-34; J. Grabowski, Poczet ksiq̨żat i księżnych mazowieckich, Kraków 2019, s. $122-123$.

14 H. Samsonowicz, Gospodarka i społeczeństwo (XIII - poczqtek XVI w.), [w:] H. Samsonowicz (red.), dz. cyt., s. 259, 340-344, 346-348; T. Lalik, Uwagi o rozwoju miast mazowieckich i Warszawy, „Studia Warszawskie” 1975, t. 13: Warszawa średniowieczna, z. 2, A. Gieysztor (red.), s. 48-51. 
północno-wschodnich rubieżach swojej dzielnicy. Później na większą skalę kontynuował to jego następca ${ }^{17}$.

Między majem 1373 r. a styczniem 1374 r. Siemowit III wyznaczył dzielnice synom: Januszowi I, który otrzymał ziemie ciechanowską, zakroczymską, warszawską i wiską, oraz Siemowitowi IV. Dopuścił ich też do współrządzenia - zaczęli oni bowiem wystawiać dokumenty we własnym imieniu. Ojciec zachował dla siebie politykę zagraniczną, ustawodawstwo, zwierzchność jurysdykcyjną i prawo ingerowania w sprawach wojskowości, donacji oraz finansów ${ }^{18}$. W 1379 r. Siemowit III podyktował nowe zasady sukcesji. Janusz otrzymał przyrzeczenie Mazowsza wschodniego, czyli ówczesnych ziem czerskiej, warszawskiej, liwskiej, zakroczymskiej, wyszogrodzkiej i ciechanowskiej ${ }^{19}$. Obszar ten był dwukrotnie większy od dzielnicy przeznaczonej bratu, lecz był słabiej rozwinięty ekonomicznie, rzadziej zaludniony i mniej dogodny klimatycznie, więc wymagał bardziej doświadczonego i roztropnego gospodarza ${ }^{20}$. Podział ten zaczął obowiązywać po zgonie Siemowita III w dniu 16 czerwca 1381 r. $^{21}$

Janusz kontynuował politykę swojego ojca. Utrzymał dobre stosunki z Ludwikiem Węgierskim, a po jego śmierci zachował wręcz neutralność w sporze o tron krakowski, gdy zabiegał o niego Siemowit IV. Później swoją wierność dochowywał królowej Jadwidze. Gdy na Litwie doszło do konfliktu między książętami, w 1382 r. Janusz zajął na krótko część Podlasia. Początkowo trzymał stronę raczej swojego szwagra Witolda, udzielając mu schronienia w potrzebie, jednak po nawiązaniu unii polsko-litewskiej w 1386 r. złożył hołd lenny nowemu królowi Władysławowi Jagielle. W 1391 r. otrzymał od niego część Podlasia w prawo dziedziczne. Po usunięciu zagrożenia ze strony Litwy Janusz skupił się na zabezpieczaniu księstwa przed krzyżakami, m.in. budując mury wokół Warszawy oraz umocnienia w Złotorii nad Narwią. Podstępne uprowadzenie księcia przez krzyżaków ostatecznie zaważyło na jego złych stosunkach z państwem zakonnym ${ }^{22}$.

W polityce wewnętrznej Janusz dążył do rozwoju osadnictwa na słabo zaludnionych, północnych i wschodnich obszarach jego księstwa. Nadawał ziemię, immunitety ekonomiczne (zastrzegając jednak pewne powinności na swoją rzecz) i przenosił wsie na prawo chełmińskie ${ }^{23}$. Z okresu pierwszych lat rządów - do śmierci ojca - znane są 23 dokumenty wystawione przez Janusza ${ }^{24}$. Dotyczyły one głównie nadań wsi, wójtostw, prawa poboru cła na rzekach, prawa chełmińskiego oraz zwolnień poddanych z określonych powinności.

17 H. Samsonowicz, A. Supruniuk, dz. cyt., s. 272-273; J. Senkowski, dz. cyt., s. 101.

18 H. Samsonowicz, A. Supruniuk, dz. cyt., s. 275-276; M. Wilska, Ksiqż̇e Janusz Starszy, Warszawa 1986, s. 9-10.

$19 \quad$ NKDM 3, nr 216, 224.

20 T. Lalik, dz. cyt., s. 35.

21 H. Samsonowicz, A. Supruniuk, dz. cyt., s. 277-278; J. Grabowski, Poczet..., dz. cyt., s. 125.

22 M. Wilska, dz. cyt., s. 13, 17-19.

23 Tamże, s. 20-21; J. Senkowski, dz. cyt., s. 101, 108-112, 116-117.

24 NKDM 3, nr 163, 169, 171, 175, 178, 180, 182, 186, 190, 191, 196, 200, 203, 204, 211, 229, 230, $245,256,259,264,267,270$. 
W celu poprawienia potencjału gospodarczego księstwa Janusz obejmował opieką kupców, prowadził przemyślaną politykę celną, ale przede wszystkim wykorzystywał korzyści płynące z urbanizacji ${ }^{25}$. Jego istotną zasługą dla rozwoju państwa było lokowanie na prawie chełmińskim i nadawanie przywilejów ponad 20 miastom $^{26}$. Do 1400 r. wydał dziesięć takich dokumentów, w tym osiem dla dóbr książęcych i dwa dla rycerskich ${ }^{27}$.

Książę wsławił się jako prężny budowniczy. Od początku XV w. stawiał nowe i rozbudowywał istniejące zamki (m.in. w Ciechanowie, Czersku, Wyszogrodzie, Liwie) oraz fundował murowane kościoły. Doprowadził również do podniesienia warszawskiego kościoła św. Jana do rangi kolegiaty, a w Warszawie wybudował swoją główną siedzibę ${ }^{28}$.

„Homo inter sue etatis principes sapientissimus et insignis, qui iusta faciendo iudicia terram suam in optimam reduxerat culturam. Adeo in gubernacione terre sue modestus, ut speculum ceterorum nominaretur et exemplar" - pisał Jan Długosz o Januszu I pod zapiską o jego śmierci ${ }^{29}$. Jakkolwiek wypowiedź kronikarza utrzymana jest w stylu panegirycznym, to historiografia zgodnie zalicza księcia do grona najwybitniejszych władców Mazowsza ${ }^{30}$.

Od dziejów politycznych Mazowsza przejdę teraz do pojęcia lokacji. W polskiej historiografii tym terminem zazwyczaj określa się zakładanie nowych wsi i miast lub przenoszenie istniejących na prawo niemieckie ${ }^{31}$. Przedsięwzięcie to rozpoczynał właściciel ziemski, zlecając zasadźcy m.in. wytyczenie granic gruntów i sprowadzenie osadników. Zasadźca otrzymywał w zamian uprzywilejowane stanowisko w nowej społeczności, posadę sędziego (sołtysa, wójta). Czerpał on dochody z kar sądowych, otrzymywał zwykle większy i wolny od powinności nadział ziemi oraz inne, różne pożytki ${ }^{32}$.

\footnotetext{
M. Wilska, dz. cyt., s. 22.

J. Grabowski, Poczet..., dz. cyt., s. 138; T. Lalik, dz. cyt., s. 53.

27 Różan (1378) - NKDM 3, nr 200; Błonie (1380) - NKDM 3, nr 245; Sochocin (1385) - A. Włodarski (wyd.), Metryka księstwa mazowieckiego z XV-XVI wieku, t. 2, Warszawa 1930, nr 526; Goszczyn (1386) - AGAD, Zb. perg., 766; Czersk (1386) - AGAD, MK, 9, k. 194v-195v; tamże, 18, k. 86-86v; Nasielsk (1386) - B. Ulanowski (wyd.), Dokumenty kujawskie i mazowieckie przeważnie z XIII wieku, Kraków 1887, s. 237, nr 51; Warka (1395) - AGAD, Zb. perg., 4165, k. 1v-2; Wyszogród (1398) - J.T. Lubomirski (wyd.), Kodeks dyplomatyczny Księstwa Mazowieckiego, Warszawa 1863, nr 131; Ciechanów (1400) - tamże, dodatek, nr 8; Łomża (1400) - AGAD, Zbiór Ignacego Kapicy Milewskiego „Kapicjana”, 57, s. 75-78.

28 M. Wilska, dz. cyt., s. 23-24, 30-41.

${ }^{29}$ K. Baczkowski, M. Kowalczyk, J. Mrukówna, K. Ożóg, C. Pirożyńska, D. Turkowska, J. Wyrozumski (red.), J. Długosz, Annales seu cronicae incliti regni Poloniae, ks. 11: 1413-1430, Warszawa 2000, s. 242; kronikarz podaje nieprawidłowy rok śmierci Janusza I, tj. 1428 zamiast 1429 - zob. J. Grabowski, Poczet..., dz. cyt., s. 142.

31 M. Gołembiowski, Lokacje miast na prawie chełmińskim, [w:] Z. Zdrójkowski (red.), Księga pamiątkowa 750-lecia prawa chelmińskiego, Toruń 1990, s. 231.

32 S. Szczur, Historia Polski. Średniowiecze, Kraków 2007, s. 219-220; T. Jurek, E. Kizik, Historia Polski do 1572, Warszawa 2013, s. 200-201.
} 
Lokacja na prawie niemieckim w założeniu miała przekładać się na poprawienie stanu skarbu właściciela ziemskiego, gdyż dotychczasowy model gospodarki i system prawa książęcego nie przynosiły już zadowalających zysków. Środkiem realizacji tego celu było przyciągnięcie nowych osadników oraz zapewnienie im swobodnej działalności przynoszącej dochody pieniężne, w przypadku miast w handlu i rzemiośle. Aby to osiągnąć, książę, jako uosobienie władzy legislacyjnej, musiał nadać tym ludziom prawo, które odpowiednio regulowałoby stosunki nowego typu gospodarki, a także zwolnić ich z uciążliwych powinności na swoją rzecz $^{33}$.

Lokacje miast wiązały się przede wszystkim z nadaniem wspólnocie podmiotowości prawnej i immunitetu sądowego, czyli wyłączenia ich spod jurysdykcji urzędników państwowych, wyznaczenia sędziego rozpatrującego sprawy mieszczan oraz określenia zasad prawnych, według których mają funkcjonować ${ }^{34}$. Zmiany zachodziły też w gospodarce miasta, która odtąd miała opierać się o model gospodarki towarowo-pieniężnej. Oprócz tego miasto ulegało przekształceniom przestrzennym: wytyczano plac targowy - rynek, szachownicowy układ ulic i regularne działki ${ }^{35}$.

Na Mazowszu wzorowano się szczególnie na prawie lokacyjnym, które obowiązywało w krzyżackim Chełmnie i Toruniu na mocy przywileju z 1233 r., później powtórzonego z pewnymi zmianami w $1251 \mathrm{r} \cdot{ }^{36}$ Przywilej ten zawierał postanowienia obowiązujące zarówno mieszkańców lokowanych miast, przybywających do nich, jak i żyjących w całej ziemi chełmińskiej ${ }^{37}$. Najistotniejszymi - choć nielicznymi - przepisami były te, które gwarantowały pewną autonomię miasta. Mieszczanie otrzymali bowiem prawo wyboru odpowiedniego dla władz zakonnych sędziego, który miał samodzielnie rozsądzać niektóre przestępstwa w mieście (z zastrzeżeniem przestępstw krwawych) ${ }^{38}$. Oprócz tego przywilej przewidywał udział rajców miejskich w rozwiązywaniu wątpliwości prawnych, również dla innych miast lokowanych na wzór Chełmna i Torunia, uniezależniając tym ich od Magdeburga. W kwestiach sądownictwa przywilej stanowił, że w sądach

33 H. Samsonowicz, Gospodarka..., dz. cyt., s. 363-364; M. Bogucka, H. Samsonowicz, Dzieje miast i mieszczaństwa w Polsce przedrozbiorowej, Wrocław 1986, s. 45, 50; S. Szczur, dz. cyt., s. 222; T. Jurek, E. Kizik, dz. cyt., s. 199.

34 J. Bardach, Historia państwa i prawa Polski, t. 1: Do połowy XV wieku, Warszawa 1973, s. 206-208; H. Samsonowicz, Gospodarka..., dz. cyt., s. 363.

35 M. Bogucka, H. Samsonowicz, dz. cyt., s. 45; T. Jurek, E. Kizik, dz. cyt., s. 206-208.

36 S. Russocki, K. Pacuski, Ustrój polityczny i prawo, [w:] H. Samsonowicz (red.), dz. cyt., s. 431; K. Zielińska-Melkowska (wyd.), Przywilej chełmiński 1233 i 1251, W. Wróblewski (tłum.), Toruń 1986, s. 34-51.

${ }_{37}$ J. Luciński, Przywilej chełmiński z 1233 r., jego treść oraz dzieje jego postanowień, [w:] Z. Zdrójkowski (red.), dz. cyt., s. 81-86.

38 Trzeba podkreślić, że zarówno w Magdeburgu, jak i w później lokowanych miastach krzyżackich sędzia był mianowany przez władze zwierzchnie, toteż istnieją wątpliwości, czy przepis ten był przestrzegany też w Chełmnie i Toruniu - J. Luciński, dz. cyt., s. 96; J. Bieniak, Recepcja prawa chełmińskiego na Kujawach i ziemi dobrzyńskiej w średniowieczu, [w:] Z. Zdrójkowski (red.), dz. cyt., s. 201. 
miejskich miało obowiązywać prawo magdeburskie, lecz wysokość kar miała być o połowę niższa niż tamże. Ponadto zwalniał mieszczan od nadmiernych powinności na rzecz zakonu, lakonicznie gwarantował swobodę handlu, a także prawo dziedziczenia ziemi przez potomków obu płci. Zastrzegał zaś m.in. kontrolę zakonu nad obrotem ziemią, obowiązek opłaty czynszu i dziesięciny oraz służby wojskowej przez większych posiadaczy ${ }^{39}$.

W tym miejscu należy zaznaczyć, że już Stanisław Pazyra zauważył, iż wiele miast mazowieckich w momencie lokacji na prawie niemieckim miało wcześniej charakter miejski. Mogły to być według niego ośrodki targowe, spełniające gospodarcze cechy miast, albo miasta istniejące już na prawie niemieckim - były bowiem określane jako „,civitates” i „oppida” lub posiadały instytucje prawa niemieckiego. Późniejszy, znany przywilej miał być powtórzeniem albo rozszerzeniem pierwotnego ${ }^{40}$. Kwestię tę rozwinął Stanisław Russocki, zestawiwszy przypadki miast, dla których wydano przywilej dotyczący wójtostwa kilka lub kilkadziesiąt lat wcześniej niż wystawiono kolejny akt zezwalający mieszczanom na korzystanie z prawa chełmińskiego ${ }^{41}$. Uzupełnieniem tych spostrzeżeń jest analiza dwóch przywilejów dla Różana Janusza Grabowskiego ${ }^{42}$. Jak się też okazuje, nie jest to odrębna cecha Mazowsza, gdyż taka sytuacja miała miejsce w sąsiedniej ziemi chełmińskiej i na Kujawach ${ }^{43}$. Z tego wszystkiego wynika fakt, że lokacja miast w tym rejonie nie była pojedynczym aktem, a długim procesem, w trakcie którego pan mógł nadać kilka przywilejów. Pierwszym, najważniejszym, był dokument z poleceniem lokacji, adresowany do zasadźcy, innym był przywilej udzielany wspólnocie mieszczan ${ }^{44}$. Stąd też wątpliwości, co uznać za właściwy akt lokacji.

Odtworzenie dokładnego przebiegu lokacji mazowieckich miast na prawie niemieckim w XIII i XIV w. jest niemożliwe z powodu niezachowania się większości pierwszych dokumentów lokacyjnych ${ }^{45}$. Dlatego przy próbie orientacyjnego określenia czasu lokacji trzeba kierować się innymi poszlakami. Pierwszą jest kwestia nazewnictwa - określenie ośrodka mianem „oppidum” lub „civitas” sugeruje, że miał on gospodarcze lub prawne cechy organizacji miejskiej, choć nie przesądza to wcale o rządzeniu się według prawa niemieckiego ${ }^{46}$. Drugą poszlaką jest występowanie w źródłach instytucji prawa niemieckiego - sołtysa lub wójta. Trzecią jest informacja, że inna miejscowość została lokowana na wzór danego ośrodka. Czwartą zaś, niedającą dużej pewności, może być fakt lokowania na prawie niemieckim wsi, która znajdowała się w bliskim sąsiedztwie większego ośrodka, późniejszego miasta. Wówczas i ono mogło już funkcjonować na prawie niemieckim. Niemniej

\footnotetext{
J. Luciński, dz. cyt., s. 90-93, 96-98, 125-127, 133-137.

S. Pazyra, Geneza i rozwój miast..., dz. cyt., s. 94, 179.

S. Russocki, dz. cyt., s. 189-195; H. Samsonowicz, Gospodarka..., dz. cyt., s. 363.

J. Grabowski, Przywileje..., dz. cyt., s. 7-21.

J. Bieniak, dz. cyt., s. 207-208, 213-214.

4 S. Russocki, dz. cyt., s. 194-195; T. Lalik, dz. cyt., s. 47; H. Samsonowicz, Gospodarka..., dz. cyt., s. 363; M. Gołembiowski, dz. cyt., s. 230, 232.

45 T. Lalik, dz. cyt., s. 46-47.

$46 \quad$ S. Russocki, dz. cyt., s. 189.
} 
problematyka lokacji miast na Mazowszu wymaga nowego opracowania, gdyż ostatnia monografia Stanisława Pazyry ${ }^{47}$ oraz zestawienie Henryka Samsonowicza ${ }^{48}$ zdają się częściowo nieaktualne wraz z napływem nowo publikowanych źródeł ${ }^{49}$.

Nie ulega jednak wątpliwości, że do połowy XIV w. niewiele ośrodków na Mazowszu cieszyło się prawem miejskim ${ }^{50}$. Najstarszym miastem był Płock, którego pierwszy dokument lokacyjny z 1237 r. jest znany ${ }^{51}$. Zniszczenie miasta w wyniku najazdów w następnych dziesięcioleciach wymusiło ponowne lokowanie miasta na prawie niemieckim u schyłku XIII w. przez Bolesława II ${ }^{52}$. Książę ten przypuszczalnie na początku XIV w. lokował też Warszawę, gdy wydzielono księstwo warszawskie i utworzono tam kasztelanię ${ }^{53}$, lecz wątpliwości co do funkcjonowania na prawie niemieckim rozwiewa dopiero odnotowanie w $1333 \mathrm{r}$. warszawskiego wójta ${ }^{54}$. Jeśli chodzi o inne miasta, znajdujące się później w dzielnicy Janusza I, to kolejną była Warka - w 1321 r. odnotowano ją jako „oppidum”, choć jej wójtów dopiero w 1352 r. ${ }^{55}$ Podobnie Zakroczym, który w dokumencie z 1333 r. był „civitas”, a najpóźniej w 1373 r. funkcjonował na prawie chełmińskim $^{56}$. Od połowy wieku akcja kolonizacyjna przyspieszyła. W 1350 r. być może miastem był Czersk (prawo niemieckie pewne w 1363 r.) ${ }^{57}$, a w 1355 r. Tarczyn ${ }^{58}$. Przed 1357 r. został lokowany Pułtusk przez biskupa płockiego Klemensa ${ }^{59}$, być

\footnotetext{
S. Pazyra, Geneza..., dz. cyt.

48 H. Samsonowicz, Gospodarka..., dz. cyt., s. 390-392.
}

49 Przede wszystkim: NKDM 2; NKDM 3; A. Supruniuk, Uzupełnienia i uwagi do „Nowego kodeksu dyplomatycznego Mazowsza”, część III: „Dokumenty z lat 1356-1381”, „Studia Źródłoznawcze” 2002, t. 40, s. 107-165; K. Pacuski, Uzupełnienia i sprostowania do „Nowego kodeksu dyplomatycznego Mazowsza”, część III: „,dokumenty z lat 1356-1381”, [w:] tamże, s. 167-200; J. Grabowski, Jeszcze uzupełnienia do „Nowego kodeksu dyplomatycznego Mazowsza”, część III: „Dokumenty z lat 1356-1381”, [w:] tamże, 2003, t. 41, s. 71-76; por. T. Lalik, dz. cyt., s. 33-34.

$50 \quad$ H. Samsonowicz, Gospodarka..., dz. cyt., s. 364.

51 S.M. Szacherska (wyd.), Zbiór dokumentów i listów miasta Płocka, t. 1: 1065-1495, Warszawa 1975, nr 9; S. Pazyra, Geneza..., dz. cyt., s. 89-93.

$52 \quad$ S.M. Szacherska (wyd.), dz. cyt., nr 18; T. Lalik, dz. cyt., s. 42.

53 A. Wolff, K. Pacuski (oprac.), T. Jurek (red.),Słownik historyczno-geograficzny ziemi warszawskiej w średniowieczu, Warszawa 2013, s. 297-298; T. Jurek (red.), S. Prinke (oprac. informatyczne), Słownik historyczno-geograficzny ziem polskich $w$ średniowieczu, edycja elektroniczna, www. słownik.ihpan.edu.pl, hasło: Warszawa - kasztelania (dostęp: 22.12.2021); S. Pazyra, Geneza..., dz. cyt., s. 95-105; A. Gieysztor, Od redakcji, „Studia Warszawskie” 1975, t. 13: Warszawa średniowieczna, z. 2, A. Gieysztor (red.), s. 5; T. Lalik, dz. cyt., s. 42-43.

54 NKDM 2, nr 211; o badaczach widzących we wczesnym sołtysie (wójcie) instytucję prawa polskiego patrz: S. Russocki, dz. cyt., s. 189-190.

55 NKDM 2, nr 160, 317; S. Pazyra, Geneza..., dz. cyt., s. 94; tenże, Geneza i rozwój miasta Warki, [w:] B. Dymek i in. (red.), Dzieje Warki 1321-1971. Studia i materiały, Warszawa 1975, s. 48-50.

$56 \quad$ NKDM 2, nr 207; NKDM 3, nr 133; K. Pacuski, Możnowładztwo i rycerstwo ziemi gostynińskiej w XIV i XV wieku, Warszawa 2009, s. 416.

57 Kodeks Dyplomatyczny Wielkopolski, t. 3, nr 1301; Nowy Kodeks Dyplomatyczny Mazowsza, cz. 3, $\mathrm{nr}$ 68; T. Zagrodzki, Czersk. Zamek i miasto historyczne, Warszawa 1996, s. 51.

$58 \quad$ NKDM 2, nr 337.

59 NKDM 3, nr 234; S. Pazyra, Geneza..., dz. cyt., s. 93-94, 111; T. Lalik, dz. cyt., s. 42-43; Z. Morawski, Dzieje Pułtuska w średniowieczu, [w:] H. Samsonowicz, R. Lolo (red.), Dzieje Pułtuska, t. 1: Do 1795 roku, Pułtusk 2016, s. 77-78. 
może też Ciechanów ${ }^{60}$, Przasnysz ${ }^{61}$ i Wyszogród, obok którego została ulokowana na prawie niemieckim książęca wieś Rębowo $0^{62}$. W $1368 \mathrm{r}$. prawem niemieckim cieszył się już Liw ${ }^{63}$, w 1373 r. zaś Czerwińsk ${ }^{64}$ i Ostrołęka ${ }^{65}$. Siemowit III do swojej śmierci prawdopodobnie nie wydał więcej żadnego przywileju lokacyjnego, ale w 1378 r., czyli jeszcze za życia księcia-seniora, starszy syn Janusz polecił lokację na prawie chełmińskim leżącego w jego dzielnicy Różana ${ }^{66}$, a w 1380 r. wydał przywilej dla mieszczan z Błonia, w którym zawarł m.in. zezwolenie na używanie prawa chełmińskiego ${ }^{67}$.

W momencie śmierci Siemowita III na całym Mazowszu mogło istnieć powyżej 20 miast, co przy ponad $34000 \mathrm{~km}^{2}$ powierzchni księstwa przekładało się na średnio jedno miasto na $1700 \mathrm{~km}^{268}$. I choć prawie wszystkie te miasta (prócz Liwu i Ostrołęki) znajdowały się w bardziej zaludnionej, zachodniej części kraju, to nawet ona pozostawała słabo zurbanizowana. Rzeczą charakterystyczną dla Mazowsza było też łączenie cech osadnictwa miejskiego i wiejskiego nawet przez większe ośrodki, co przejawiało się m.in. tym, że obok handlu i rzemiosła mieszczanie zajmowali się jednocześnie rolnictwem ${ }^{69}$.

Jednym z takich miasteczek było w późniejszym średniowieczu Błonie. Niestety niedostatek źródeł archeologicznych i pisanych nie pozwala na rekonstrukcję dziejów wczesnośredniowiecznego osadnictwa w jego rejonie. Od X w. wyraźniej zauważalne jest osadnictwo nad Bzurą w okolicach późniejszego Sochaczewa, którędy przechodził jeden ze szlaków z Płocka do Małopolski, natomiast tereny na lewym brzegu Wisły zdają się być wówczas rzadko zamieszkałe ${ }^{70}$. Jak wyglądał obszar pomiędzy nimi - nie wiadomo. Pewne wskazówki może dać nazwa miejscowa, urobiona od tak samo brzmiącego rzeczownika o etymologii bałtosłowiańskiej, oznaczającego równinę, łąkę, pastwisko, rozległą, często podmokłą

60 NKDM 3, nr 19; T. Lalik, dz. cyt., s. 44; K. Pacuski, Ciechanów średniowieczny na tle dziejów Mazowsza w świetle źródeł pisanych, [w:] A.K. Sobczak (red.), Ciechanów - szkice z historii miasta, Ciechanów 2016, s. 54-55.

61 T. Lalik, dz. cyt., s. 45.

62 NKDM 3, nr 11; B. Nowicka, Wyszogród. Zarys dziejów, Wyszogród 1971, s. 15-16.

63 NKDM 3, nr 98; L. Zalewski, Ziemia liwska. Ludzie - miejscowości - wydarzenia, Warszawa 2002, S. 42 .

64 NKDM 3, nr 135; H. Samsonowicz, Czerwińsk na średniowiecznym Mazowszu, [w:] R. Lolo (red.), Czerwińsk nad Wisłą. Historia - rozwój - wyzwania, Czerwińsk nad Wisłą 2018, s. 28. NKDM 3, nr 136; Z. Niedziałkowska, Ostrołęka. Dzieje miasta, Warszawa 1975, s. 22-27.

$66 \quad$ NKDM 3, nr 200; J. Grabowski, Przywileje..., dz. cyt., s. 7-21.

67 NKDM 3, nr 245.

68 Według stanu z drugiej połowy XVI w. Mazowsze, bez wchodzącego w jego skład za panowania Siemowita III powiatu goniądzkiego, liczyło $33493 \mathrm{~km}^{2}$ - A. Dunin-Wąsowiczowa, Podziały administracyjne, [w:] W. Pałucki (red.), Atlas historyczny Polski. Mapy szczegółowe XVI wieku, t. 7: Mazowsze w drugiej połowie XVI wieku, cz. 2: Komentarz. Indeksy, Warszawa 1973, Aneks I, s. $59-60$.

69 H. Samsonowicz, Gospodarka..., dz. cyt., s. 362-363, 368-372.

70 T. Lalik, dz. cyt., s. 36-38; J. Antoniewicz, Początki osadnictwa w Sochaczewie i okolicach w okresie wczesnośredniowiecznym (do XIII wieku), [w:] S. Russocki (red.), Dzieje Sochaczewa i ziemi sochaczewskiej, Warszawa 1970, s. 17-26. 
przestrzeń ${ }^{71}$. Miasto Błonie doskonale wpisuje się w ten źródłosłów. Położone jest bowiem w centrum wschodniej części Równiny Łowicko-Błońskiej, poprzecinanej licznymi ciekami wodnymi w dorzeczu Bzury ${ }^{72}$. Od strony północnej i wschodniej Błonie okala rzeka Utrata (do XIX w. zwana jeszcze Nrową lub Mrową ${ }^{73}$ ), prawy dopływ Bzury, a od południa i zachodu niewielka rzeczka Rokitnica, uchodząca do Utraty. Przed regulacją ich biegów tworzyły one szerokie rozlewiska, pomiędzy którymi rozpościerał się teren - niejako wyspa - o niewątpliwie dogodnych warunkach obronnych ${ }^{74}$. Okoliczny krajobraz co najmniej od XVI-XVII w. charakteryzował się otwartością i brakiem większych skupisk drzew, ze względu na silną eksploatację ziemi w celach rolniczych ${ }^{75}$. Wynikało to przede wszystkim z wyjątkowej żyzności tutejszych gleb ${ }^{76}$. Wychodząc od etymologii nazwy, można przypuścić, że podobny stan krajobrazu istniał już w XIII w., gdy źródła pisane odnotowały Błonie, i już wtedy sprzyjał intensywnemu osadnictwu ${ }^{77}$.

Nad brzegiem Nrowy w I połowie XIII w. powstał dwuczłonowy gród ze stożkiem i majdanem. Podczas badań archeologicznych zlokalizowano na nim duży, pochodzący z tego okresu ceglany dwór. Jest to jedyny znany budynek tego typu na Mazowszu, znajdujący analogie tylko w rezydencji Henryka Brodatego w Legnicy. Ponadto znajdowały się tu pracownie złotnicza, rogowiarska - wykorzystu-

71 K. Rymut, Nazwy miast Polski, Wrocław 1980, s. 37; S. Rospond, Słownik etymologiczny miast i gmin PRL, Wrocław 1984, s. 31; red. K. Rymut, Nazwy miejscowe Polski. Historia-pochodzenie - zmiany, t. 1: A-B, Kraków 1996, s. 225-226; U. Bijak, Nazwy miejscowe południowej części dawnego województwa mazowieckiego, Kraków 2001, s. 23; A. Brückner, Słownik etymologiczny języka polskiego, t. 1:A-O, Kraków 1927, s. 31; W. Boryś, Słownik etymologiczny języka polskiego, Kraków 2005, s. 32.

72 J. Kondracki, Geografia regionalna Polski, Warszawa 2009, s. 191-193.

73 J. Duma, Nazwy rzek lewobrzeżnego Mazowsza (z całym dorzeczem Pilicy), Warszawa 1999, s. 30 31; F. Sulimierski, B. Chlebowski, W. Walewski (red.), Słownik geograficzny Królestwa Polskiego i innych krajów słowiańskich, t. 6, Warszawa 1885, s. 767; tamże, t. 15, cz. 2, Warszawa 1902, s. 676; A. Wolff, K. Pacuski (oprac.), T. Jurek (red.), dz. cyt., s. 181; T. Jurek (red.), S. Prinke (oprac. informatyczne), dz. cyt., hasło: Nrowa (Warszawa).

${ }_{74}$ M.W. Solarz, dz. cyt., s. 11-18; por. plany i mapy z XIX w. - tenże, Błonie na dawnych mapach, Błonie 2017; A. Bartoszewicz, H. Bartoszewicz, Kartografia miast Mazowsza i ziemi dobrzyńskiej do końca XIX wieku, Warszawa Pułtusk 2012, s. 43-44, 176-177.

75 „W okolicy Warszawy ziemia jest bardzo urodzajna w przynoszeniu plonów, a przede wszystkim w rodząca pszenicę. Lecz koło Błonia daje się odczuć wielki brak drzewa, ponieważ po wykarczowaniu lasów wszystko zajmują uprawne pola." - J. Święcicki, Topografia czyli opis Mazowsza, S. Pazyra (wyd.), H. Pazyrzyna (tłum.), Warszawa 1974, s. 148-151; o braku drzew w najbliższej okolicy może też świadczyć np. przywilej króla Zygmunta III Wazy z 1599 r. dla mieszczan błońskich, w którym zezwala im na wyrąb drzewa budulcowego w odległym o kilka kilometrów lesie kampinoskim - AGAD, Ks. ziem. i gr. warsz., seria 4, 26, s. 1396-1397; por. rekonstrukcję zasięgu lasów w drugiej połowie XVI w. - W. Pałucki (red.), Atlas historyczny Polski. Mazowsze w drugiej połowie XVI wieku, cz. 1: Mapa, plany, Warszawa 1973; zasięg lasów na początku XIX w. - D. Gilly, Spezialkarte von Südpreußen, Berlin 1802-1803, arkusze D II i D III.

76 J. Kondracki, Geografia..., dz. cyt., s. 191-193; F. Sulimierski, dz. cyt., s. 250.

77 Podobnie uważa T. Kiersnowska, Płock, Czersk i Błonie; trzy ośrodki wczesnomiejskie w XI-XIII w. na Mazowszu, [w:] L. Leciejewicz (red.), Miasto zachodniosłowiańskie w XI-XII wieku. Społeczeństwo - kultura, Wrocław 1991, s. 49; por. mapę: Próba rekonstrukcji krajobrazu Polski wczesnohistorycznej, [w:] K. Buczek, Ziemie polskie przed tysiqcem lat, Kraków 1967, po s. 100. 
jąca głównie róg i kości jeleni - oraz liczne przedmioty ceramiczne pochodzenia zachodnioeuropejskiego $^{78}$. Ze względu na okazałość obiektu jego budowę przypisuje się księciu Konradowi I, który po wydzieleniu starszym synom dzielnic w 1238 r. i przekazaniu Płocka Bolesławowi zatrzymał dla siebie ziemie łęczycką, sieradzką i czerską ${ }^{79}$. Nie ma jednak źródeł świadczących o pobycie Konrada I w Błoniu, a pierwszym księciem związanym z tym miejscem był Siemowit I. Niewykluczone, że ojciec przeznaczył mu tutejszy gród za siedzibę ${ }^{80}$.

W tym samym czasie nad Rokitnicą, niecałe $2,5 \mathrm{~km}$ na południowy zachód od grodu, w miejscu, gdzie mogła istnieć osada targowa ${ }^{81}$, wzniesiono istniejący do dziś kościół. Była to niewątpliwie fundacja książęca, gdyż w 1257 r. to na prośbę księcia Siemowita I poświęcono w nim dwa ołtarze ${ }^{82}$. Imponujących rozmiarów ceglana, trzynawowa bazylika o czterech przęsłach, z niezrealizowanymi wieżami w fasadzie zachodniej, łącząca cechy późnoromańskie i wczesnogotyckie, była zapewne przeznaczona na siedzibę zgromadzenia kanoniczego i kancelarii książęcej. W 1261 r. bowiem Siemowit I wystawił tutaj dokument, a świadkowali mu trzej kanonicy: Jan Rawa, Proces i Andrzej ${ }^{83}$. Świątynia mogła jednocześnie spełniać funkcję obronną: strażnicy przy przeprawie przez rzekę (wiadomo, że później istniał tam most ${ }^{84}$ ) oraz refugium dla lokalnej ludności ${ }^{85}$.

W najbliższej okolicy istniały również gródek w Osieku i hipotetyczny gródek w Kopytowie, oba usytuowane w strategicznych miejscach nad Nrową ${ }^{86}$, a także kilka odnotowanych w końcu XIII w. wsi, wchodzących w skład domeny książęcej oraz duchownej (biskupa poznańskiego i archidiakona czerskiego) ${ }^{87}$. Wszystko to tworzyło zespół osadniczy, jakby ośrodek wczesnomiejski, znajdujący analogie wokół odległych o ok. 25 km grodów w Trojanowie (Sochaczewie) i Jazdowie (Warszawie) ${ }^{88}$.

78 T. Kiersnowska, Trzynastowieczna siedziba ksiq̨żęca w Błoniu, „Kwartalnik Historii Kultury Materialnej” 1971, t. 19, nr 3, s. 448-459; A. Cofta, Wyniki badań na grodzisku wczesnośredniowiecznym w Błoniu, pow. Grodzisk Mazowiecki w latach 1949-51, [w:] Materiały wczesnośredniowieczne, t. 3, Warszawa 1951, s. 1-51.

79 A. Teterycz-Puzio, Konrad I Mazowiecki, kniaź wielki lacki (1187/89 - 31 sierpnia 1247), Kraków 2019, s. 136.

T. Kiersnowska, Trzynastowieczna..., dz. cyt., s. 457.

Taż, Płock..., dz. cyt., s. 50.

NKDM 2, nr 35.

Tamże, $\mathrm{nr} 44$.

Tamże, nr 80.

5 A. Tomaszewski, Romańskie kościoły z emporami zachodnimi na obszarze Polski, Czech i Węgier, Wrocław 1974, s. 138, 145-150; E. i A. Tomaszewscy, Późnoromański kościół św. Trójcy w Błoniu na Mazowszu, [w:] Architektura dawna a współczesność, W. Puget (red.), „Studia i Materiały do Teorii i Historii Architektury i Urbanistyki” 1982, t. 16, s. 120-126; M.W. Solarz, Błonie. Ksiq̨żęce..., dz. cyt., s. 16.

86 A. Niewęgłowski, Grodzisko w Błoniu-Osieku, woj. Warszawa, w świetle badań w latach 1975 i 1976, „Sprawozdania Archeologiczne” 1984, t. 36, s. 193-212; S. Suchodolski, Kopytów, pow. Pruszków, „Informator archeologiczny. Badania rok 1972”, Warszawa 1973, s. 251.

${ }_{87}$ NKDM 2, nr 80, 101.

88 T. Kiersnowska, Trzynastowieczna..., dz. cyt., s. 460-461; taż, Płock..., dz. cyt., s. 50; H. Rutkowski, Rozwój przestrzenny Sochaczewa od XIII do XVIII wieku, [w:] S. Russocki (red.), dz. cyt., s. 32. 
W 1262 r. miał miejsce niszczycielski najazd litewsko-ruski, podczas którego zdobyto Jazdów, zamordowano Siemowita I, a jego syna Konrada wzięto do niewoli. Rok później inna wyprawa spustoszyła okolice Łowicza ${ }^{89}$. W 1281 r. znów padł Jazdów, tym razem w wyniku najazdu Bolesława II na dzielnicę brata ${ }^{90}$, a w 1286 r. Konrad II w odwecie i przy wsparciu Rusinów oraz Litwinów zniszczył Sochaczew ${ }^{91}$. Również i gród w Błoniu zakończył okres swojego funkcjonowania w wyniku najazdu zbrojnego, o czym świadczą zniszczenia, porzucone zapasy mięsa oraz liczne groty bełtów i strzał u podnóża wału ${ }^{92}$. Źródła archeologiczne sugerują jednak, że gród mógł funkcjonować jeszcze w ostatniej ćwierci XIII w., a z tym miejscem (jeśli nie z innym, nieznanym grodem w pobliskim Rokitnie) można wiązać wzmiankowany dwukrotnie w 1282 r. urząd kasztelana rokickiego ${ }^{93}$. Zatem bardziej prawdopodobne jest, że zniszczenie grodu nastąpiło w trakcie wojny między Siemowitowicami.

W kościele Świętej Trójcy w Błoniu nie odkryto śladów zniszczenia, ale już najpóźniej na przełomie XIII i XIV w. nastąpiła jego gruntowna przebudowa, podczas której m.in. w miejsce drewnianych stropów (być może spalonych) wzniesiono sklepienia krzyżowo-żebrowe ${ }^{94}$. Wówczas też książę Konrad II zrezygnował z patronatu nad kościołem, gdyż w 1288 r. przekazał go wraz z uposażeniem kanonikom regularnym z Czerwińska ${ }^{95}$, by w 1294 r. zostać pochowanym w czerwińskim opactwie ${ }^{96}$.

Ośrodek książęcy w Błoniu stracił na znaczeniu ${ }^{97}$ i na blisko wiek niemal znikł ze znanych źródeł pisanych. Zachowało się więcej informacji o pobliskich miejscowościach, położonych w dorzeczu Nrowy-Utraty i Rokitnicy. W 1313 r. Siemowit II nadał rycerzowi wieś Radzikowo ${ }^{98}$, a w 1326 r. Trojden I odstąpił biskupowi poznańskiemu wieś Domaniew ${ }^{99}$. Ten sam książę w 1333 albo 1334 r. prawdopodobnie świętował w Błoniu Boże Narodzenie, ponieważ 27 grudnia wydał tu dokument ${ }^{100}$. Z $1333 \mathrm{r}$. pochodzi też pierwsza informacja o istnieniu w sąsiednim Rokitnie dwóch kościołów: pod wezwaniem świętego Wojciecha i świętego Ja-

A9 $\quad$ A. Gieysztor, Działania wojenne Litwy w r. 1262 i zdobycie Jazdowa, [w:] E. Halicz i in. (red.), Studia historyczne Stanisławowi Herbstowi na sześćdziesięciolecie urodzin w upominku uczniowie, koledzy, przyjaciele, Warszawa 1967, s. 5-14; G. Błaszczyk, Dzieje stosunków polsko-litewskich od czasów najdawniejszych do współczesności, t. 1: Trudne poczq̨tki, Poznań 1998, s. 42-44; G. Białuński, Studia z dziejów plemion pruskich i jaćwieskich, Olsztyn 1999, s. 112. A. Gieysztor, Jazdów - poprzednik Warszawy, [w:] K. Jażdżewski (red.), Liber Iosepho Kostrzewski octogenario a veneratoribus dicatus, Wrocław 1968, s. 508.

$91 \quad$ G. Błaszczyk, dz. cyt., s. 52.

92 T. Kiersnowska, Trzynastowieczna ..., dz. cyt., s. 456-457.

93 NKDM 2, nr 67, 68.

94 A. Tomaszewski, dz. cyt., s. 146-149; E. i A. Tomaszewscy, dz. cyt., s. 124-125.

$95 \quad$ NKDM 2, nr 80.

96 J. Grabowski, Poczet..., dz. cyt., s. 53.

${ }_{97}$ T. Lalik, dz. cyt., s. 40-41.

$98 \quad$ NKDM 2, nr 135.

99 Tamże, nr 184.

100 Tamże, nr 211. 
kuba $^{101}$, a w 1365 r. Siemowit III przeniósł na prawo niemieckie okoliczne wsie należące do rycerstwa (Łowczewo) i błońskiego klasztoru (Zwola, Wawrzyszewo, Nieznajewo $)^{102}$. Dopiero od kolejnego dokumentu, interesującego nas przywileju z 1380 r., wraca częstsze występowanie Błonia w źródłach ${ }^{103}$.

Jego oryginał nie dotrwał do dzisiejszych czasów - został prawdopodobnie zniszczony w czasie II wojny północnej w latach 1655-1660 104 - ale jego treść jest znana z pięciu zachowanych kopii. Najstarsza z nich to oblata w księdze grodzkiej warszawskiej z 1552 r., która została sporządzona na podstawie oryginału, przedłożonego przez pisarza miasta Błonia ${ }^{105}$. Drugą kopią jest transumpt króla Stefana z 1580 r. według transumptu Zygmunta II Augusta z 1563 r., również przepisanego $\mathrm{z}$ oryginału ${ }^{106}$. Jakkolwiek te wersje zawierają nieznaczne różnice w kilkunastu słowach, nie wpływa to na sens całości. Dwa następne - transumpty Augusta II z 1729 r. ${ }^{107}$ oraz Stanisława Augusta z 1765 r. (w dwóch egzemplarzach) ${ }^{108}$ - sporządzono już na podstawie wcześniejszych kopii.

Z braku oryginału analiza zewnętrzna jest niemożliwa, ale dokument musiał mieć formę taką samą, jak inne zachowane dokumenty Janusza z okolicznych lat - pergamin z pieczęcią pieszą większą, przywieszoną na zielonym, jedwabnym sznurze ${ }^{109}$.

Dokument został spisany według standardowego wzoru z kompletnymi protokołem wstępnym, korpusem i eschatokołem (protokołem końcowym). Rozpoczyna go szablonowa inwokacja, po niej następuje arenga, w której wydawca uzasadnia spisanie dokumentu ulotnością pamięci ludzkiej (typ „memoria-oblivio”"10), a dalej zwyczajowa formuła promulgacji i intytulacja wystawcy: „Johannes Dei gracia dux Vissnensis, Varschouiensis, Zakroczimiensis dominus et heres Cziechonouiensis". Taka sama tytulatura w pełnej albo skróconej formie występuje we wszystkich znanych dokumentach Janusza I do 16 czerwca 1381 r., co jasno świadczy o nieobowiązywaniu jeszcze nowego podziału Mazowsza z 1379 r. ${ }^{111}$ Po intytulacji następuje narracja, według której motyw nadania przywileju był

\footnotetext{
Tamże, nr 205.

102 Tamże, nr 80, 82.

103 Por. A. Wolff, K. Pacuski (oprac.), T. Jurek (red.), dz. cyt., s. 8-12; T. Jurek (red.), S. Prinke (oprac. informatyczne), dz. cyt., hasło: Błonie (Warszawa).

104 „Praw i przywilejów żadnych ci [błońscy - przyp. aut.] mieszczanie przed nami nie produkowali dla stracenia ich przez wojnę szwedzką. Twierdzą jednak, iż te ich prawa przez Szwedów zabrane miały by się zostać w Toruniu.” - A. Wawrzyńczyk (wyd.), Lustracja województwa mazowieckiego XVII wieku, cz. 2: 1660-1661, Warszawa 1989, s. 104.

09 Np. AGAD, Zb. perg., 1503 (1379 r.), 1505, 1506 (1382 r.); S.K. Kuczyński, Pieczęcie ksiq̨żq̨t mazowieckich, Wrocław 1978, s. 329-330.

110 J. Grabowski, Kancelarie ksiażęęce na Mazowszu, [w:] T. Jurek (red.), Dyplomatyka staropolska, Warszawa 2014, s. 229.

111 J. Grabowski, Dynastia Piastów mazowieckich, Kraków 2016, s. 346.
} 
ekonomiczny - chęć ulepszenia i wzbogacenia księstwa ${ }^{112}$. Niemal identyczna narracja towarzyszyła innym przywilejom lokacyjnym dla miast i wsi ${ }^{113}$. W tym przypadku miało temu służyć obdarzenie miasta Błonia prawami pozwalającymi na jego łatwiejsze urządzenie i zasiedlenie ${ }^{114}$. Wystawca zaznaczył, że nadanie przywileju nastąpiło również w odpowiedzi na prośby jego odbiorców, „civium universitatis Blonensis”, czyli wspólnoty mieszczan ${ }^{115}$. To określenie dobitnie świadczy o istnieniu już wykształconej gminy jako podmiotu prawnego ${ }^{116}$.

Dyspozycja w najszerszym ujęciu dotyczyła dwóch obszarów: prawa karnego oraz skarbowości. Pierwszym w kolejności postanowieniem księcia było nadanie mieszczanom pełnego prawa do sądzenia i karania przestępstw wszelkiej wagi - tak wielkich, jak i małych ${ }^{117}$. Wymieniono najważniejsze czyny zabronione, mające należeć do właściwości sądu miejskiego: morderstwo, podpalenie, pozbawienie członków, przemoc fizyczną i seksualną, kradzież, fałszerstwo orzeczenia sądowego bądź uprawnienia, wagi i miary ${ }^{118}$, pozostawiając ten katalog otwartym na inne możliwe występki ${ }^{119}$. Zauważalna jest wyjątkowa szerokość uprawnienia. Jakkolwiek w ustępie zaznaczono, że sądzenie i karanie ma być zgodne ze wszystkimi postanowieniami prawa chełmińskiego, to książę zrzekł się ingerowania również w sprawach przestępstw krwawych, inaczej niż regulował to przywilej chełmiński ${ }^{120}$.

Sąd miejski otrzymał prawo sądzenia wszystkich przestępstw, które zostałyby popełnione w obrębie granic miasta, bliżej nieokreślonych w dokumencie. Dotyczyło to sprawców spośród mieszczan lub innych ludzi przynależących do miasta $^{121}$. Ta druga kategoria nie jest do końca jasna: mogło tu chodzić o pospólstwo, czyli mieszkańców niecieszących się pełnym dopuszczeniem do prawa miejskiego, albo o poddanych miastu chłopów. Jakkolwiek nie ma żadnych przekazów

$112, \ldots[\ldots]$ cupientes divino nobis suffragante auxilio ducatum et dominium nostrum in melius reformare et in uberiores fructus convertere, necnon peramplius indesinenter augere [...]”.

113 J. Grabowski, Kancelarie..., dz. cyt., s. 230-231.

$114, \ldots[. .$.$] volentes eciam ipsam civitatem Blone sic nuncupatam aliquibus iuribus gaudere et perlu-$ strare, ut eo facilius eadem civitas pro ubertate nostri ducatus et dominii valeat locari cicius et possideri $[\ldots] "$.

115, ,...] specialiter tamen peticionibus variis fidelium nostrorum civium universitatis Blonensis graciosius acclinati $[\ldots] "$.

116 M. Bogucka, H. Samsonowicz, dz. cyt., s. 55-56.

117 „Damus itaque civibus nostris ante omnia atque in omnibus causis, tam magnis, quam parvis [...] iucandi, sentenciandi, puniendi et condemnandi plenam et omnimodam potestatem [...]”.

$118, \ldots[.$.$] puta furti, homicidii, incendii, membrorum mutilacionis, violencie, stupri, false iusticie,$ ponderis et mensure, seu ulne [...]".

$119, \ldots[\ldots]$ ceterisque viciis, quibuscumque nominibus vocitentur $[\ldots] ”$.

120 „Damus [...] iucandi, sentenciandi, puniendi et condemnandi plenam et omnimodam potestatem, prout ipsorum ius Theutonicum originale Culmense in omnibus suis articulis postulat et requirit; por. przywilej chełmiński: Verumtament de maioribus culpis, ut sunt homicidia, sanguinis effusio et (hiis) similia, iudex absque fratrum nostrorum assensu nil remittat” - K. Zielińska-Melkowska (wyd.), dz. cyt., s. 36-37; J. Luciński, dz. cyt., s. 97.

$121, \ldots[. .$.$] in graniciis et metis memorate civitatis perpetratorum et perpetrancium inter homines dicte$ civitatis, necnon inter homines ad eandem civitatem pertinentes [...]”. 
świadczących o wsiach lub innych majątkach ziemskich podległych miastu ${ }^{122}$, może dotyczyło to ludzi pracujących na rolach mieszczańskich w obrębie granic miasta. Książę natomiast jasno zastrzegł, że przedstawiciele rycerstwa mieli odpowiadać tylko przed książęcym sądem, sprawowanym osobiście lub przez dostojników.

Ponadto uwięzieniu i osądzeniu przez miejski sąd podlegali obcy poddani wszelkiej kategorii, którzy popełniliby w mieście przestępstwo ${ }^{123}$. Gdyby zaś takiż zbiegł przed uwięzieniem i nie chciałby zjawić się przed sądem miejskim, rozprawa sądowa miała się zakończyć, ale przestępstwo nigdy nie ulegało przedawnieniu. Zbieg ów nie mógł mieć swobodnego wstępu w granice miasta, dopóki całkowicie nie zadośćuczyniłby wspólnocie miejskiej. Mieszczanie otrzymali prawo zatrzymania w granicach miasta zbiega w dowolnym momencie jego życia, doprowadzenia go przed sąd i ukarania zgodnie z tutejszym prawem ${ }^{124}$.

W zdaniu zamykającym prawnokarną część dyspozycji doprecyzowano, że w przypadku zabójstwa popełnionego wśród mieszczan wyrok na ciele i mieniu miał być wydany według prawa miejskiego bez jakichkolwiek przeszkód ze strony książęcych dygnitarzy ${ }^{125}$. Zapewne miało to ostatecznie rozwiewać wątpliwości co do zrzeczenia się przez księcia sądów nad przestępstwami krwawymi i zabezpieczać miasto przed samowolą urzędników ${ }^{126}$.

Postanowienia te tworzyły w granicach miasta Błonia obszar niemal całkowicie wyłączony spod sądownictwa książęcego. Dalej następowała część dyspozycji dotycząca skarbowości. Na początku książę zwolnił mieszczan z wszelkich, niezgodnych z prawem niemieckim powinności i zwyczajowych danin prawa polskiego, którymi dotychczas byli obciążeni na jego $\mathrm{rzecz}^{127}$.

Następnie udzielił tutejszym mieszczanom prawo wolnego przejazdu ze swoimi towarami przez wszystkie komory celne na obszarze księstwa bez uiszczania

${ }^{122}$ A. Wolff, K. Pacuski (oprac.), T. Jurek (red.), dz. cyt., s. 8-12; T. Jurek (red.), S. Prinke (oprac. informatyczne), dz. cyt., hasło: Błonie (Warszawa).

${ }^{123}$ „Si vero in aliquo maleficio peragendo quis extraneus, vel militalis, rusticus, episcopalis et monachalis hominibus civitatis valuerit detineri, ipso iudicio civili iudicetur". W wersji opublikowanej w NKDM 3 w miejscu ,valuerit” umieszczony został czasownik ,voluerit” (NKDM 3, nr 245, s. 262), co zupełnie zmienia sens zdania, sugerując jakąś dobrowolność w poddaniu się miejskiemu sądowi.

124 „Si autem peracto maleficio idem extraneus, ut preficitur, detencionem predictorum civium effugerit et iuri civili memorato parere noluerit, extunc causa de ipso more consueto iudicialiter diffinita tamdiu malefactor ingressu civitatis et granicierum eiusdem carebit libere, donec sufficiens satisfactio per ipsum malefactorem eidem civitati integraliter et ex toto impensa fuerit, alioquin si malefactor huiusmodi contumax et rebellis in ipsa civitate et graniciis eiusdem per dictos cives quandocumque temporibus vite sue potuerit detineri, iuxta excessum ipsius et delictum, quemadmodum ipsum ius civile decreverit, puniatur".

125 „Preterea homicidio, quod absit, inter predictos cives occurrente sine aliquo impedimento procurancium nostrorum, tam in corpore, quam in rebus ipsorum more consueto civili iudicentur".

126 H. Samsonowicz, Gospodarka..., dz. cyt., s. 364.

127 „Absolvimus insuper et exemimus sepefatos cives ab omnibus aggravacionibus et consuetudinibus iuris Polonicalis, quibus antea solebantur aggravari, ab omnibus angariis, preangariis et vexacionibus universis, quocumque nomine censeantur, que plerique ipsum ius Theutonicum sepissime perturbare consueverunt, facientes ipsos liberos penitus et absolutes". 
$\mathrm{cła}^{128}$. Nie zwolnił ich natomiast z cła w przypadku przekroczenia granic państwa $^{129}$. Możliwe, że był to element książęcej polityki gospodarczej, polegającej na ograniczaniu eksportu, co miało zapobiegać wysokim cenom towarów w księstwie ${ }^{130}$, ale może przede wszystkim chodziło o pobudzanie handlu z rozwijającą się dopiero wschodnią częścią dzielnicy Janusza. Trzeba pamiętać, że kilka kilometrów na zachód od Błonia przechodziła granica pomiędzy ziemią warszawską a sochaczewską, która należała już do Siemowita IV ${ }^{131}$. W odległości ok. $26 \mathrm{~km}$, czyli dnia drogi pieszej, istniał duży ośrodek w Sochaczewie, z którym błońscy mieszczanie niewątpliwie utrzymywali kontakty handlowe ${ }^{132}$. Jest raczej pewne, że bracia nie uznawali zwolnień z cła dla poddanych drugiej strony. W $1398 \mathrm{r}$. zawarli bowiem porozumienie, w którym znosili obciążenia celne dla kupców obu księstw tylko w nowo tworzonych komorach, ale cła między dzielnicami były pobierane w starych komorach jeszcze w XV w. ${ }^{133}$

Po dyspozycji następuje koroboracja, poświadczająca przywieszenie pieczęci książęcej, dalej datacja i testacja. Dokument ten sporządzono w czwartek w przeddzień świętej Małgorzaty w roku 1380, czyli 12 lipca, w Zakroczymiu. Data roczna nie budzi zastrzeżeń - dzień tygodnia i miesiąca są ze sobą zgodne ${ }^{134}$. Świadkami wydania przywileju byli: Marcin sędzia ${ }^{135}$, Łaszcz podkomorzy ${ }^{136}$, Piotrko chorąży ${ }^{137}$ ciechanowscy, Paweł sędziaa ${ }^{138}$, Junosza podkomorzy ${ }^{139}$, Falęta chorąży ${ }^{140}$

128 Najpewniej nie dotyczyło to zwolnienia z myta - J. Senkowski, dz. cyt., s. 79-80.

129 „Demum eciam prenarratis nostris civibus per omnia et singula loca thelonei in dominio nostro antiquitus observata cum omnibus mercibus ipsorum propriis sine aliqua requisicione thelonearii indulgemus transitum liberum et securum ita, quod ipsum theoloneum, ut prescribitur, dare non debebunt; hoc tamen presupposito et declarato, quod cum extra metas ducatus nostri cum mercibus suis versus partes alienas quascumque pretexti cives intenderint proficisci, tunc theolonea nostra iuxta consuetudinem ante vigentem in ducatu nostro exsolvere teneantur".

130 J. Senkowski, dz. cyt., s. 63-64.

131 Por. stan późniejszy, zapewne pokrywający się z granicami z końca XIV w.: W. Pałucki (red.), dz. cyt.

132 H. Rutkowski, dz. cyt., s. 36.

${ }^{133}$ Iura Masoviae terrestria, t. 1: 1228-1471, J. Sawicki (wyd.), Warszawa 1972, nr 49; J. Senkowski, dz. cyt., s. 66.

134 Tak też odczytali średniowieczną datację i przełożyli na współczesną konwencję wydawcy NKDM 3, nie mając żadnych wątpliwości.

135 Marcin Babka z Babic w ziemi warszawskiej, z rodu Dołęgów; w latach 1363-1388 sędzia ciechanowski, w 1385-1391 wojewoda mazowiecki - M. Wilska, Mazowieckie środowisko dworskie Janusza Starszego. Studium społeczne, Warszawa 2012, s. 103.

136 Łaszcz (Łaskarz) z Wrońsk w ziemi zakroczymskiej, z rodu Prawdziców; w latach 1374-1388 podkomorzy ciechanowski - tamże, s. 102.

137 Piotr z rodu Prusów; w latach 1374-1394 chorąży ciechanowski - tamże, s. 114.

138 Paweł Piórko z Łowczewa (Łuszczewa) w ziemi sochaczewskiej, z rodu Prusów; w latach 13741389 sędzia zakroczymski i wyszogrodzki - tamże, s. 110.

139 Junosza z Zaborowa (Małego) w ziemi warszawskiej, czasem jako z Głuska w ziemi sochaczewskiej, z rodu Junoszów; w latach 1374-1389 podkomorzy zakroczymski, w 1376-1381 starosta generalny, w 1389-1409 sędzia wyszogrodzki i zakroczymski, a w 1392-1409 także sędzia ciechanowski - tamże, s. 100.

140 Falęta z Bielin, z rodu Junoszów; w latach 1376-1393 chorąży zakroczymski - tamże, s. 90. 
zakroczymscy oraz Więcław podkanclerzy i kapelan książęcy ${ }^{141}$, który był dyktatorem dokumentu, o czym świadczy umieszczona przy jego imieniu formuła „qui presentia habuit" 142 .

Dla niektórych ośrodków, które funkcjonowały na prawie niemieckim przed 1381 r., książę Janusz I wydał nowe przywileje. Otrzymały je: Czersk (1386 r.) $)^{143}$, Warka (1395 r.) $)^{144}$, Wyszogród (1398 r. $)^{145}$, Ciechanów (1400 r.) ${ }^{146}$, Różan (1403 r.) $)^{147}$, Stare Miasto Warszawa (1413 r.) $)^{148}$, Ostrołęka $(1427 \text { r. })^{149}$. Nadał też przywileje nowym, prywatnym miastom: Sochocinowi (1385 r.) $)^{150}$ i Nasielskowi (1386 r.) $)^{151}$ oraz dobrom książęcym: m.in. Goszczynowi (1386 r.) $)^{152}$, Łomży (1400 i 1418 r.) ${ }^{153}$ i Grójcowi (1419 r.) ${ }^{154}$. Postanowienia poszczególnych przywilejów Janusza I i jednego przywileju Siemowita III (który warto w tym zestawieniu wziąć pod uwagę) prezentuje tabela w Aneksie 1.

Pierwsze przywileje dla Ostrołęki (1373 r.) ${ }^{155}$, Łomży (1400 r.) i Goszczyna (1386 r.) były nadaniami dziedzicznych wójtostw wraz z uposażeniem. Składało się na nie kilka łanów ziemi, udział w dochodach z kar sądowych (trzeci denar) oraz inne dochody, np. z młyna, opłaty przewoźnej przez rzekę itp. Wójt łomżyński został ponadto zobowiązany do służby wojskowej, a przywilej ostrołęcki explicite nadawał też mieszczanom ostrołęckim możność stosowania prawa chełmińskiego. Przywilej dla Różana (1378 r.) ${ }^{156}$ również jest nadaniem wójtostwa, lecz zawiera on więcej szczegółów związanych z lokacją. Książę dosłownie wyraził w nim polecenie lokowania miasta na prawie chełmińskim, a także zwolnił mieszczan z odpowiedzialności przed sądem swoim i swoich urzędników, wyznaczając właściwy im sąd wójtowski. Dotyczyło to również przestępstw krwawych $^{157}$.

141 Więcław (Wacław), w latach 1379-1384 szef kancelarii i kapelan dworski, wcześniej jako podkanclerzy, od poł. 1382 r. kanclerz dworski, w 1384 r. kanclerz ziemski zakroczymski i pleban tarczyński - tamże, s. 124.

${ }_{142}$ J. Grabowski, Kancelarie..., dz. cyt., s. 218, 223, 233.

143 AGAD, MK, 9, k. 194v-195v; tamże, 18, 86-86v; tłum. na j. polski - F.A. Kozłowski, Dzieje Mazowsza za panowania ksiq̨żqt, Warszawa 1858, s. 572-575.

144 AGAD, Zb. perg., 4165, k. 1v-2.

145 J.T. Lubomirski (wyd.), dz. cyt., nr 131.

146 Tamże, dodatek, nr 8.

147 J. Grabowski, Przywileje..., dz. cyt., aneks, s. 19-21.

148 T. Wierzbowski (wyd.), Przywileje królewskiego miasta stołecznego Starej Warszawy, 1376-1772, Warszawa 1913, nr 8.

149 Z. Niedziałkowska, dz. cyt., s. 27-28.

150 A. Włodarski (wyd.), dz. cyt., nr 526.

151 B. Ulanowski (wyd.), dz. cyt., s. 237, nr 51.

152 AGAD, Zb. perg., 766.

153 AGAD, Zbiór Ignacego Kapicy Milewskiego „Kapicjana”, 57, s. 75-78; tamże, 60, s. 253-262.

154 J.T. Lubomirski (wyd.), Księga ziemi czerskiej 1404-1425, poprzedzona wstępem historycznym, Warszawa 1879, s. LIV; AGAD, Ks. ziem. i gr. warsz., ser. 2, 11, k. 957-962.

155 NKDM 3, nr 136.

156 Tamże, nr 200.

157 J. Grabowski, Przywileje..., dz. cyt., s. 10-12. 
Reszta przywilejów zawierała postanowienia niemal zbieżne i ubrane w prawie taką samą szatę słowną, jak w przywileju błońskim. W przywileju dla Czerska (1386 r.) rozwinięto ustęp dotyczący zwolnienia mieszczan z powinności. Wyartykułowano wyjątki, które stanowiły o obowiązku opłacania przez mieszczan czynszu od domów, karczem, warsztatów rzemieślniczych i pól miejskich na dzień św. Marcina, czyli 11 listopada. Oprócz tego mieli oni płacić pół grosza od grzywny dochodu w przypadku wesela dzieci książęcych, dostania się księcia lub jego synów do niewoli oraz wykupu zastawionej ziemi państwowej. Byli też zobowiązani do dostarczenia $\mathrm{w}$ razie potrzeby księciu, osobiście biorącemu udział w wyprawie, wozu. Między tymi postanowieniami umieszczono zwroty: „iuxta aliarum civitatum nostrarum consuetudinem”; „qualiter super alias civitates nostras pro tunc generaliter duxerimus". Świadczyłoby to o obowiązywaniu tych norm w Błoniu i innych miastach książęcych. Zapewne dlatego w kolejnych przywilejach zrezygnowano z tego ustępu, pozostawiając tę kwestię niejako domyślnie. Inaczej niż w przywilejach błońskim i czerskim książę udzielił mieszczanom prawo do pobudowania łaźni, postrzygalni i wagi, z których miasto i wójt mieli czerpać dochody. Niemniej Błonie miało później te dwie pierwsze budowle. Już w 1418 r. wzmiankowany jest postrzygacz z Błonia ${ }^{158}$, a lustracja z 1569 r. wprost wymienia łaźnię i postrzygalnię ${ }^{159}$. Warto zaznaczyć, że w żadnym przywileju nie ma mowy o wolniźnie, która zazwyczaj była ważnym postanowieniem przy lokacji miast ${ }^{160}$.

Wszystko to potwierdza tezę wcześniejszych badaczy, że mazowieckie lokacje na prawie niemieckim były procesem, podczas którego wydawano różne typy przywilejów w przeciągu nawet kilkudziesięciu lat. Pierwszy z nich, rozpoczynający bieg procesu lokacji, adresowany był do zasadźcy. Zdaje się, że jedynym takim znanym na Mazowszu jest pierwszy przywilej dla Różana, a inne podobne to nadania istniejących już wójtostw. Skoro zaś nadawane wójtostwa były dziedziczne, to dokumenty z przywilejem przechowywane były w obrębie jednej rodziny i miały charakter bardziej prywatny niż publiczny. Nie dziwne zatem, że pierwsze przywileje z poleceniem lokacji nie zachowały się tak licznie ${ }^{161}$.

Drugi typ przywileju w procesie lokacji - niewątpliwie wieńczący ją - adresowany był do rozwiniętej wspólnoty mieszczan, może posiadającej już przedstawicielstwo w postaci rady miejskiej. Książę wydawał go dopiero w momencie, kiedy miał pewność, że lokacja się powiedzie. Było to posunięcie pragmatyczne, mające na celu zabezpieczenie się przed skutkami nieudanych lokacji. Wszelkiego typu zwolnienia dla poddanych dozowano, aby nie uszczuplać aż nazbyt książęcych

\footnotetext{
158 A. Wolff (wyd.), Księga ławnicza miasta Nowej Warszawy, t. 1: 1416-1485, Wrocław 1960, nr 14.

159 AGAD, ASK, XLVI, 143b, k. 12v.

160 M. Bogucka, H. Samsonowicz, dz. cyt., s. 51-53.

161 T. Lalik, dz. cyt., s. 46-47.
} 
dochodów ${ }^{162}$. Tego typu dokumenty zachowały się licznie, ponieważ miały wysoką wartość dla całej społeczności miasta.

Przywilej księcia Janusza dla Błonia z 1380 r. ewidentnie reprezentował drugi typ. Pozostawia to otwartą kwestię, kiedy zlecono lokację miasta zasadźcy. Przywilej dla wójta nie zachował się, a pierwszy znany błoński wójt pojawia się w źródle z 1421 r. Był nim Bartłomiej Montlus z pobliskiego Czubina ${ }^{163}$ i przez ponad następne stulecie wójtostwo prawdopodobnie nieprzerwanie było w posiadaniu jego potomków ${ }^{164}$. Dopiero w 1542 r. zostało ono wykupione przez Marcina Wolskiego, podkomorzego i podskarbiego koronnego, a jednocześnie starostę błońskiego, od Stanisława Czubińskiego. Tenże nie wylegitymował się z przywileju na wójtostwo, tłumacząc, że dokument spłonął podczas pożaru miasta $^{165}$.

Jedyną, ewentualną poszlaką, którą można się kierować w odpowiedzi na pytanie o pierwszy przywilej, jest fakt przeprowadzania lokacji na prawie niemieckim w bliskim sąsiedztwie Błonia. W 1365 r. książę Siemowit III przeniósł na prawo niemieckie prywatną wieś Łowczewo (obecnie Stary Łuszczewek w gm. Błonie) ${ }^{166}$. Takie samo pozwolenie wydał dla klasztoru czerwińskiego i błońskiego, więc lokowane zostały pobliskie wsie Zwola, Wawrzyszewo i Nieznajewo (obecnie Pass, Wawrzyszew i Górna Wieś w gm. Błonie) ${ }^{167}$. Natomiast w 1377 r. książę Janusz przeniósł na prawo chełmińskie wieś Kanie, odległą od Błonia o $12 \mathrm{~km}$, później znajdującą się w obrębie powiatu błońskiego ${ }^{168}$.

Pewne jest, że polecenie lokacji Błonia zostało wydane wcześniej niż 1380 r., może przez księcia Siemowita III, a może i wcześniej. Przywilej Janusza I był natomiast ostatnim etapem długiego procesu powstawania wspólnoty miejskiej nowego typu.

\section{Aneks 1. Postanowienia przywilejów lokacyjnych}

(+ - występuje,

- - nie występuje,

? - nie wiadomo) ${ }^{1}$

1 Źródła: patrz przyp. 9, 143-156.

S. Russocki, dz. cyt., s. 195.

AGAD, Ks. ziem. i gr. warsz., ser. 1, 1, k. 29.

164 A. Wolff, K. Pacuski (oprac.), T. Jurek (red.), dz. cyt., s. 9-10; T. Jurek (red.), S. Prinke (oprac. informatyczne), dz. cyt., hasło: Błonie (Warszawa).

165 AGAD, MK, 57, k. 322v-324.

166 NKDM 3, nr 80.

167 Tamże, nr 82.

168 Tamże, nr 191; A. Wolff, K. Pacuski (oprac.), T. Jurek (red.), dz. cyt., s. 99; T. Jurek (red.), S. Prinke (oprac. informatyczne), dz. cyt., hasło: Kanie (Warszawa). 


\begin{tabular}{|c|c|c|c|c|c|c|c|c|c|c|}
\hline 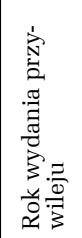 & 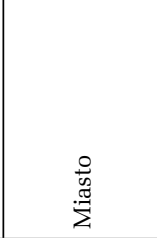 & 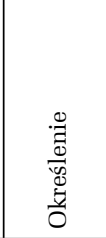 & 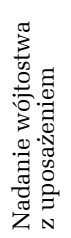 & 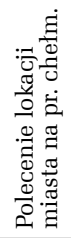 & 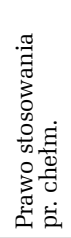 & 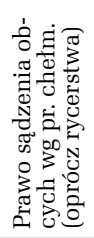 & 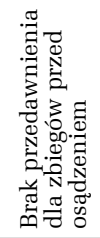 & 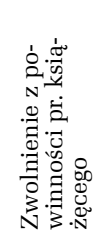 & 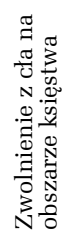 & 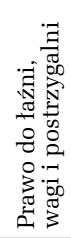 \\
\hline 1373 & \begin{tabular}{|l} 
Ostrołęka \\
(I)
\end{tabular} & $\begin{array}{l}\begin{array}{l}\text { oppi- } \\
\text { dum }\end{array} \\
\end{array}$ & + & - & + & - & - & - & - & - \\
\hline 1378 & Różan (I) & $\begin{array}{l}\text { oppi- } \\
\text { dum }\end{array}$ & + & + & + & - & - & - & - & - \\
\hline 1380 & Błonie & civitas & - & - & + & + & + & + & + & - \\
\hline 1386 & Goszczyn & civitas & + & - & + & - & - & - & - & - \\
\hline 1386 & Czersk & civitas & - & - & + & + & + & + & + & - \\
\hline 1398 & Wyszogród & civitas & - & - & + & + & + & - & + & + \\
\hline 1400 & $\begin{array}{l}\text { Ciecha- } \\
\text { nów }\end{array}$ & $\begin{array}{l}\text { oppi- } \\
\text { dum }\end{array}$ & - & - & + & + & + & - & + & + \\
\hline 1400 & Łomża (I) & \begin{tabular}{|l|}
$\begin{array}{l}\text { oppi- } \\
\text { dum }\end{array}$ \\
\end{tabular} & + & - & - & - & - & - & - & - \\
\hline 1403 & Różan (II) & civitas & - & - & + & + & + & - & + & + \\
\hline 1413 & \begin{tabular}{|l|} 
Stara \\
W-wa
\end{tabular} & civitas & - & - & + & + & + & - & + & + \\
\hline 1418 & Łomża (II) & civitas & - & - & + & + & + & - & + & + \\
\hline 1419 & Grójec & \begin{tabular}{|l}
$\begin{array}{l}\text { oppi- } \\
\text { dum }\end{array}$ \\
\end{tabular} & - & - & + & + & + & - & + & + \\
\hline 1427 & $\begin{array}{l}\text { Ostrołęka } \\
\text { (II) }\end{array}$ & $?$ & - & - & + & $?$ & $?$ & - & $?$ & + \\
\hline
\end{tabular}

\section{Aneks 2. Tekst dokumentu.}

\section{Zakroczym, 12 lipca 1380}

Ksiqż̇ę Jan nadaje przywilej miastu Błonie.

Or. nieznany

Kop. 1. Warszawa, AGAD, Ks. ziem. i gr. warsz., ser. 1, 35, s. 246-250 $0^{169}$;

Kop. 2. tamże, $M K, 123$, k. 155v-156v;

Kop. 3. tamże, Zb. perg., 4273;

Kop. 4. tamże, KK, 25, s. 521-526 $6^{170}$;

Kop. 5. tamże, Zb. perg. 4316;

Wyd. NKDM 3, nr 245.

In nomine Domini amen. Dignum et iustum est, ut ea, que principes in profectum et utilitatem suorum subditorum benignius largiuntur, ne simul cum flu-

169 Główna podstawa źródłowa niniejszej edycji.

$170 \quad$ Za NKDM 3. 
$\mathrm{xu}$ temporis a memoria hominum evanescant, necesse est, ut tam sollempnibus roborentur titulis litterarum. Noverint igitur universi, tam presentes, quam futuri, presencium litterarum noticiam habituri, quod nos Johannes Dei gracia dux Vissnensis, Varschouiensis, Zakroczimiensis dominus et heres Cziechonouiensis cupientes divino nobis suffragante auxilio ducatum et dominium ${ }^{171}$ nostrum in melius reformare et in uberiores fructus convertere, necnon peramplius indesinenter augere, specialiter tamen peticionibus variis fidelium nostrorum civium universitatis Blonensis graciosius acclinati, volentes eciam ipsam civitatem Blone sic nuncupatam aliquibus iuribus gaudere et perlustrare, ut eo facilius eadem civitas pro ubertate nostri ducatus et dominii valeat locari cicius et possideri, eosdem cives predictos speciali favore et zelo prosequentes de gracia nostre magnificencie consueta communitati civium prenominatorum iura inferius expressa damus, asscribimus, annectimus et perpetuo incorporamus locatis et locandis per nos et nostros successores predictis civibus nostris inviolabiliter temporibus perpetuis observanda.

Damus itaque civibus nostris ante omnia atque in omnibus causis tam magnis, quam parvis, puta furti, homicidii, incendii, membrorum mutilacionis, violencie, stupri, false iusticie, ponderis et mensure, seu ulne, ceterisque viciis, quibuscumque nominibus vocitentur iuxta excessum malefactorum et maleficiorum in graniciis et metis memorate civitatis perpetratorum et perpetrancium inter homines dicte civitatis, necnon inter homines ad eandem civitatem pertinentes iucandi, sentenciandi, puniendi et condemnandi plenam et omnimodam potestatem, prout ipsorum ius Theutonicum originale Culmense in omnibus suis articulis postulat et requirit; nichilominus tali condicione subinclusa, quod si, quod absit, aliquem ex nobilibus vel militibus quibuscumque ex premissis factis aliquot et aliis quibusvis in civitate nostra iamdicta, vel in metis eiusdem civitatis perpetrare contingerit, ad iudicium civile iudicari minime attrahantur, quos magnificencia nostra per nos, aut nobiles nostros pro tribunali nostro assidentes discernere reservavit.

Si vero in aliquo maleficio peragendo quis extraneus, vel militalis, rusticus, episcopalis et monachalis hominibus civitatis valuerit ${ }^{172}$ detineri, ipso iudicio civili iudicetur. Si autem peracto maleficio idem extraneus, ut preficitur, detencionem predictorum civium effugerit et iuri civili memorato parere noluerit, extunc causa de ipso more consueto iudicialiter diffinita tamdiu malefactor ingressu civitatis et granicierum eiusdem carebit libere, donec sufficiens satisfactio per ipsum malefactorem eidem civitati integraliter et ex toto impensa fuerit, alioquin si malefactor huiusmodi contumax et rebellis in ipsa civitate et graniciis eiusdem per dictos cives quandocumque temporibus vite sue potuerit detineri, iuxta excessum ipsius et delictum, quemadmodum ipsum ius civile decreverit, puniatur. Preterea homicidio, quod absit, inter predictos cives occurrente sine aliquo

171 W wyd. niepoprawnie: dominum - NKDM 3, nr 245, s. 262.

172 W wyd. niepoprawnie: voluerit - NKDM 3, nr 245, s. 262; zob. wyżej przypis 122. 
impedimento procurancium nostrorum tam in corpore, quam in rebus ipsorum more consueto civili iudicentur.

Absolvimus insuper et exemimus sepefatos cives ab omnibus aggravacionibus et consuetudinibus iuris Polonicalis, quibus antea solebantur aggravari, ab omnibus angariis, preangariis et vexacionibus universis, quocumque nomine censeantur, que plerique ipsum ius Theutonicum sepissime perturbare consueverunt, facientes ipsos liberos penitus et absolutos.

Demum eciam prenarratis nostris civibus per omnia et singula loca thelonei in dominio nostro antiquitus observata cum omnibus mercibus ipsorum propriis sine aliqua requisicione thelonearii indulgemus transitum liberum et securum ita, quod ipsum theoloneum, ut prescribitur, dare non debebunt; hoc tamen presupposito et declarato, quod cum extra metas ducatus nostri cum mercibus suis versus partes alienas quascumque pretexti cives intenderint proficisci, tunc theolonea nostra iuxta consuetudinem ante vigentem in ducatu nostro exsolvere teneantur.

In quorum omnium testimonium premissorum presentes scribi fecimus et sigilli nostri appensionis munimine roborari. Actum et datum in Zakroczim, feria quinta in vigilia beate Margarethe sub anno Domini millesimo trecentesimo octuagesimo, presentibus his testibus, nobilibus viris: Martino iudice, Lassczone succamerario, Portkone vexillifero Cziechono-uiensibus, Paulo iudice, Junossa succamerario Falentha vexillifero Zacroczimiensibus, et Venceslao vicecancellario et capellano curie nostre, qui presencia habuit in commissis et aliis quamplurimis nostris et fidedignis.

\section{Wykaz skrótów}

AGAD - Archiwum Główne Akt Dawnych.

ASK - Archiwum Skarbu Koronnego.

KK - Księgi Kanclerskie.

Ks. ziem. i gr. warsz. - Księgi ziemskie i grodzkie warszawskie.

MK - Metryka Koronna.

NKDM 2 - I. Sułkowska-Kuraś, S. Kuraś (wyd.), Nowy Kodeks Dyplomatyczny Mazowsza, cz. 2: Dokumenty z lat 1248-1355, Wrocław 1989.

NKDM 3 - I. Sułkowska-Kuraś, S. Kuraś (wyd.), Nowy Kodeks Dyplomatyczny Mazowsza, cz. 3: Dokumenty z lat 1356-1381, Warszawa 2000.

Zb. perg. - Zbiór dokumentów pergaminowych.

\section{BIBLIOGRAFIA}

\section{Źródła rękopiśmienne}

AGAD, Zbiór dokumentów pergaminowych: 766, 1503, 1505, 1506, 4165, 4273, 4316.

AGAD, Metryka Mazowiecka: 9, 18.

AGAD, Metryka Koronna: 123.

AGAD, Księgi Kanclerskie: 25. 
AGAD, Archiwum Skarbu Koronnego: XLVI, 143b.

AGAD, Księgi ziemskie i grodzkie warszawskie, ser. 1: 1, 35; ser. 2: 11; ser. 4: 26.

AGAD, Zbiór Ignacego Kapicy Milewskiego „Kapicjana”: 57, 60.

\section{Źródła drukowane}

Baczkowski K., Kowalczyk M., Mrukówna J., Ożóg K., Pirożyńska C., Turkowska D., Wyrozumski J. (red.), Długosz J., Annales seu cronicae incliti regni Poloniae, ks. 11: 1413-1430, Warszawa 2000.

Gilly D., Spezialkarte von Südpreußen, Berlin 1802-1803, arkusze D II i D III.

Grabowski J., Jeszcze uzupełnienia do „Nowego kodeksu dyplomatycznego Mazowsza”, część III: „Dokumenty z lat 1356-1381”, „Studia Źródłoznawcze” 2003, t. 41.

Kodeks dyplomatyczny Wielkopolski, t. 3: Lata 1350-1399, Poznań 1879.

Lubomirski J.T. (wyd.), Kodeks dyplomatyczny Księstwa Mazowieckiego, Warszawa 1863.

Lubomirski J.T. (wyd.), Księga ziemi czerskiej 1404-1425, poprzedzona wstępem historycznym, Warszawa 1879.

Pacuski K., Uzupełnienia i sprostowania do „Nowego kodeksu dyplomatycznego Ma-zowsza”, część III: „dokumenty z lat 1356-1381”, „Studia Źródłoznawcze” 2002, t. 40.

Rzyszczewski L., Muczkowski A. (wyd.), Kodex dyplomatyczny Polski, t. 2, cz. 2, Warszawa 1852.

Sawicki J. (wyd.), Iura Masoviae terrestria, t. 1: 1228-1471, Warszawa 1972.

Sułkowska-Kuraś I., Kuraś S. (wyd.), Nowy Kodeks Dyplomatyczny Mazowsza, cz. 2: Dokumenty z lat 1248-1355, Wrocław 1989, cz. 3: Dokumenty z lat 1356-1381, Warszawa 2000.

Supruniuk A., Uzupełnienia i uwagi do „Nowego kodeksu dyplomatycznego Mazowsza”, część III: „Dokumenty z lat 1356-1381”, „Studia Źródłoznawcze” 2002, t. 40.

Szacherska S.M. (wyd.), Zbiór dokumentów i listów miasta Płocka, t. 1: 1065-1495, Warszawa 1975.

Święcicki J., Topografia czyli opis Mazowsza, S. Pazyra (wyd.), H. Pazyrzyna (tłum.), Warszawa 1974.

Ulanowski B. (wyd.), Dokumenty kujawskie i mazowieckie przeważnie z XIII wieku, Kraków 1887.

Wawrzyńczyk A. (wyd.), Lustracja województwa mazowieckiego XVII wieku, cz. II: 1660-1661, Warszawa 1989.

Wierzbowski T. (wyd.), Przywileje królewskiego miasta stołecznego Starej Warszawy, 1376-1772, Warszawa 1913.

Włodarski A. (wyd.), Metryka księstwa mazowieckiego z XV-XVI wieku, t. 2, Warszawa 1930.

Wolff A. (wyd.), Księga ławnicza miasta Nowej Warszawy, t. 1: 1416-1485, Wrocław 1960.

Zielińska-Melkowska K. (wyd.), Przywilej chełmiński 1233 i 1251, W. Wróblewski (tłum.), Toruń 1986.

\section{Opracowania:}

Baliński M., Lipiński T., Starożytna Polska pod względem historycznym, jeograficznym i statystycznym opisana, t. 1, Warszawa 1843.

Bardach J., Historia państwa i prawa Polski, t. 1: Do połowy XV wieku, Warszawa 1973; 
Bartoszewicz A., Bartoszewicz H., Kartografia miast Mazowsza i ziemi dobrzyńskiej do końca XIX wieku, Warszawa-Pułtusk 2012.

Białuński G., Studia z dziejów plemion pruskich i jaćwieskich, Olsztyn 1999.

Bieniak J., Recepcja prawa chełmińskiego na Kujawach i ziemi dobrzyńskiej w średniowieczu, [w:] Z. Zdrójkowski (red.), Księga pamiq̨tkowa prawa chełmińskiego, t. 1, Toruń 1990.

Bieniak J., Szymczakowa A. (oprac.), Gąsiorowski A. (red.), Urzędnicy łęczyccy, sieradzcy i wieluńscy XIII-XV wieku. Spisy, Wrocław 1985.

Bijak U., Nazwy miejscowe południowej części dawnego województwa mazowieckiego, Kraków 2001.

Błaszczyk G., Dzieje stosunków polsko-litewskich od czasów najdawniejszych do współczesności, t. 1: Trudne poczq̨tki, Poznań 1998.

Błeszczyński J., Błonie, [w:] S. Orgelbrand (wyd.), Encyklopedyja powszechna, t. 3, Warszawa 1860.

Bogucka M., Samsonowicz H., Dzieje miast i mieszczaństwa w Polsce przedrozbiorowej, Wrocław 1986.

Boryś W., Słownik etymologiczny języka polskiego, Kraków 2005.

Brückner A., Słownik etymologiczny języka polskiego, t. 1: A-O, Kraków 1927.

Cofta A., Wyniki badań na grodzisku wczesnośredniowiecznym w Błoniu, pow. Grodzisk Mazowiecki w latach 1949-51, [w:] Materiały wczesnośredniowieczne, t. 3, Warszawa 1951.

Duma J., Nazwy rzek lewobrzeżnego Mazowsza (z całym dorzeczem Pilicy), Warszawa 1999.

Dunin-Wąsowiczowa A., Podziały administracyjne, [w:] W. Pałucki (red.), Atlas historyczny Polski. Mapy szczegółowe XVI wieku, t. 7: Mazowsze w drugiej połowie XVI wieku, cz. 2: Komentarz. Indeksy, Warszawa 1973.

Gawarecki W.H., Wiadomość historyczna o kościele parafialnym w mieście Błoniu, „Pamiętnik religijno-moralny" 1848, t. 14, z. 5.

Gieysztor A., Działania wojenne Litwy w r. 1262 i zdobycie Jazdowa, [w:] E. Halicz i in. (red.), Studia historyczne Stanisławowi Herbstowi na sześćdziesięciolecie urodzin w upominku uczniowie, koledzy, przyjaciele, Warszawa 1967.

Gieysztor A., Jazdów - poprzednik Warszawy, [w:] K. Jażdżewski (red.), Liber Iosepho Kostrzewski octogenario a veneratoribus dicatus, Wrocław 1968.

Gieysztor A., Od redakcji, „Studia Warszawskie” 1975, t. 13: A. Gieysztor (red.), Warszawa średniowieczna, z. 2.

Gołembiowski M., Lokacje miast na prawie chełmińskim, [w:] Z. Zdrójkowski (red.), Księga pamiq̨tkowa 750-lecia prawa chełmińskiego, Toruń 1990.

Grabowski J., Dynastia Piastów mazowieckich, Kraków 2016.

Grabowski J., Kancelarie ksiqżęce na Mazowszu, [w:] T. Jurek (red.), Dyplomatyka staropolska, Warszawa 2014.

Grabowski J., Poczet ksiq̨żąt i księżnych mazowieckich, Kraków 2019.

Grabowski J., Przywileje lokacyjne księcia mazowieckiego Janusza I dla Różana, „Rocznik Mazowiecki” 2009, t. 21.

Jurek T. (red.), Słownik historyczno-geograficzny ziem polskich w średniowieczu, edycja elektroniczna, S. Prinke (oprac. informatyczne), www.słownik.ihpan.edu.pl (dostęp: 22.12.2021). 
Jurek T., Kizik E., Historia Polski do 1572, Warszawa 2013.

Kiersnowska T., Czersk w XIII i XIV wieku. Ośrodek władzy książęcej na południowym Mazowszu, Warszawa 1986.

Kiersnowska T., Płock, Czersk i Błonie; trzy ośrodki wczesnomiejskie w XI-XIII w. na Mazowszu, [w:] L. Leciejewicz (red.), Miasto zachodniosłowiańskie w XI-XII wieku. Społeczeństwo - kultura, Wrocław 1991.

Kiersnowska T., Trzynastowieczna siedziba ksiq̨żęca w Błoniu, „Kwartalnik Historii Kultury Materialnej” 1971, t. 19, nr 3.

Kondracki J., Geografia regionalna Polski, Warszawa 2009.

Kozłowski F.A., Dzieje Mazowsza za panowania ksiq̨żąt, Warszawa 1858.

Kuczyński S.K., Pieczęcie ksiqż̨̇t mazowieckich, Wrocław 1978.

Lalik T., Uwagi o rozwoju miast mazowieckich i Warszawy, „Studia Warszawskie” 1975, t. 13, A. Gieysztor (red.), Warszawa średniowieczna, z. 2.

Luciński J., Przywilej chełmiński z 1233 r., jego treść oraz dzieje jego postanowień, [w:] Z. Zdrójkowski (red.), Księga pamiątkowa prawa chełmińskiego, t. 1, Toruń 1990.

Morawski Z., Dzieje Pułtuska w średniowieczu, [w:] H. Samsonowicz, R. Lolo (red.), Dzieje Pułtuska, t. 1: Do 1795 roku, Pułtusk 2016.

Niedziałkowska Z., Ostrołęka. Dzieje miasta, Warszawa 1975.

Niewęgłowski A., Grodzisko w Błoniu-Osieku, woj. Warszawa, w świetle badań w latach 1975 i 1976, „Sprawozdania Archeologiczne” 1984, t. 36.

Nowakowski G.W., Kamosiński J., Przyczynek do dziejów m. Błonia województwa warszawskiego, Błonie 1930.

Nowicka B., Wyszogród. Zarys dziejów, Wyszogród 1971.

Pacuski K., Ciechanów średniowieczny na tle dziejów Mazowsza w świetle źródeł pisanych, [w:] A.K. Sobczak (red.), Ciechanów - szkice z historii miasta, Ciechanów 2016.

Pacuski K., Możnowładztwo i rycerstwo ziemi gostynińskiej $w$ XIV i XV wieku, Warszawa 2009.

Pałucki W. (red.), Atlas historyczny Polski. Mapy szczegółowe XVI wieku, t. 7: Mazowsze w drugiej połowie XVI wieku, cz. 1: Mapa, plany, Warszawa 1973.

Pazyra S., Geneza i rozwój miast mazowieckich, Warszawa 1959.

Pazyra S., Geneza i rozwój miasta Warki, [w:] B. Dymek i in. (red.), Dzieje Warki 13211971. Studia i materiały, Warszawa 1975.

Pazyra S., Studia z dziejów miast na Mazowszu od XIII do poczq̨tków XX wieku, Lwów 1939.

Próba rekonstrukcji krajobrazu Polski wczesnohistorycznej, [w:] K. Buczek, Ziemie polskie przed tysiq̨em lat, Kraków 1967.

Rospond S., Słownik etymologiczny miast i gmin PRL, Wrocław 1984.

Russocki S., Etapy lokacji miejskich na Mazowszu w XIV-XV wieku, „Przegląd Historyczny” 1964, t. 55, z. 2.

Russocki S., Pacuski K., Ustrój polityczny i prawo, [w:] H. Samsonowicz (red.), Dzieje Mazowsza, t. 1, Pułtusk 2006.

Rutkowski H., Rozwój przestrzenny Sochaczewa od XIII do XVIII wieku, [w:] S. Russocki (red.), Dzieje Sochaczewa i ziemi sochaczewskiej, Warszawa 1970.

Rymut K., Nazwy miast Polski, Wrocław 1980.

Rymut K. (red.), Nazwy miejscowe Polski. Historia - pochodzenie - zmiany, t. 1: $A-B$, Kraków 1996. 
Samsonowicz H., Czerwińsk na średniowiecznym Mazowszu, [w:] R. Lolo (red.), Czerwińsk nad Wisła. Historia - rozwój - wyzwania, Czerwińsk nad Wisłą 2018.

Samsonowicz H., Gospodarka i społeczeństwo (XIII - poczq̨tek XVI w.), [w:] H. Samsonowicz (red.), Dzieje Mazowsza, t. 1, Pułtusk 2006.

Samsonowicz H., Supruniuk A., Dzieje polityczne (połowa XIV-poczqtek XVI w.), [w:] H. Samsonowicz (red.),Dzieje Mazowsza, t. 1, Pułtusk 2006.

Senkowski J., Skarbowość Mazowsza od końca XIV wieku do 1526 roku, Warszawa 1965.

Siuchniński M. (red.), Miasta polskie w tysiqcleciu, t. 2, Wrocław 1967.

Słownik geograficzny Królestwa Polskiego i innych krajów słowiańskich, F. Sulimierski,

B. Chlebowski, W. Walewski (red.), t. 1, Warszawa 1880, t. 6, Warszawa 1885, t. 15, cz. 2, Warszawa 1902.

Solarz M.W., Błonie. Ksiqżęce miasto na Mazowszu, Kwidzyn 2010.

Solarz M.W., Błonie na dawnych mapach, Błonie 2017.

Suchodolski S., Kopytów, pow. Pruszków, „Informator archeologiczny. Badania rok 1972”, Warszawa 1973.

Szczur S., Historia Polski. Średniowiecze, Kraków 2007.

Teterycz-Puzio A., Konrad I Mazowiecki, kniaź wielki lacki (1187/89 - 31 sierpnia 1247), Kraków 2019.

Tomaszewski A., Romańskie kościoły z emporami zachodnimi na obszarze Polski, Czech i Węgier, Wrocław 1974.

Tomaszewscy E. i A., Późnoromański kościół św. Trójcy w Błoniu na Mazowszu, [w:] W. Puget (red.), Architektura dawna a współczesność, „Studia i Materiały do Teorii i Historii Architektury i Urbanistyki” 1982, t. 16.

Wilska M., Ksiq̨żę Janusz Starszy, Warszawa 1986.

Wilska M., Mazowieckie środowisko dworskie Janusza Starszego. Studium społeczne, Warszawa 2012.

Wolff A., Pacuski K. (oprac.), Jurek T. (red.), Słownik historyczno-geograficzny ziemi warszawskiej w średniowieczu, Warszawa 2013.

Zagrodzki T., Czersk. Zamek i miasto historyczne, Warszawa 1996.

Zalewski L., Ziemia liwska. Ludzie - miejscowości - wydarzenia, Warszawa 2002.

\section{Town Privileges for Błonie (1380) During the Reign of Janusz I the Old}

Abstract: This article contains an analysis of the privilege issued by Duke Janusz I the Old for his city of Błonie in 1380. In it, he granted the townspeople the right to apply the Chełmno law, released them from the obligation of the ducal law (ius ducal) and customs duties throughout the country. The comparative study shows that the same provisions contained privileges later granted to other urban communities in the eastern district of Mazovia. In order to present the context of issuing the privilege, the work also presents an outline of the political and economic situation in Mazovia in the second half of the 14th century, the beginnings and course of the municipal location charter under German law of Mazovian cities and the history of Błonie before 1380 . The purpose of this work was to answer the question about the 
date of the municipal location charter of Błonie, bearing in mind the existence of at least two types of privileges that play an important role in the location process. The privilege for Błonie turned out to be the end of this process, which allowed to postpone the date of the city's beginnings.

Keywords: Błonie, municipal location charter, Chełmno law, Janusz I the Old 